\title{
The Nature of Recruitment and De-Recruitment and Its Implications for Management of ARDS
}

\author{
Richard H Kallet, Michael S Lipnick, and Gregory D Burns
}

\author{
Introduction \\ Brief Overview of Recruitment Maneuvers in ARDS \\ Physics and Physiology of Recruitment: Pressure and Time \\ Temporal Aspects of Lung Recruitment \\ Creep: Fast Versus Slow Pulmonary Compartments \\ Evidence Supporting Creep Phenomenon in ARDS \\ Selecting Inspiratory Time During Recruitment Maneuver \\ Mechanics of Recruitment and De-Recruitment \\ Distribution of TOP and Recruitment \\ Interpretive Limitations of Mechanistic Studies of Recruitment \\ Sponge Theory and Superimposed Hydrostatic Pressures \\ PEEP and De-Recruitment \\ Superimposed Pressure, De-Recruitment, and ARDS Severity \\ Elevated Intra-Abdominal Pressure in ARDS \\ Thoracoabdominal Mechanics, De-Recruitment, and Intra-Abdominal \\ Hypertension \\ Intra-Abdominal Hypertension and ARDS \\ Impact of PEEP on Volume Distribution in ARDS \\ Ambiguous and Perplexing Nature of Recruitment Phenomena \\ Radiologic Factors \\ Rheologic Factors \\ Histopathologic Factors \\ Direct Versus Indirect Injury and Injury Severity \\ $P_{\text {plat }}$ and PEEP During LPV \\ Optimizing Oxygenation and Minimizing Risk of Atelectrauma \\ Implications of Slow Pulmonary Compartments \\ Hemodynamic Consequences of OLV \\ Potential Risk of Ventilator-Induced Lung Injury \\ Implications of the ART Study \\ Summary
}

Recruitment maneuvers in ARDS are used to improve oxygenation and lung mechanics by applying high airway pressures to reopen collapsed or obstructed peripheral airways and alveoli. In the early 1990s, recruitment maneuvers became a central feature of a variant form of lungprotective ventilation known as open-lung ventilation. This strategy is based on the belief that repetitive opening and closing of distal airspaces induces shear injury and therefore contributes both to ventilator-induced lung injury and ARDS-associated mortality. However, the largest multi-center randomized controlled trial of open-lung ventilation in moderate to severe ARDS reported that recruitment maneuver plateau pressures of $50-60 \mathrm{~cm} \mathrm{H}_{2} \mathrm{O}$ were associated with significantly higher mortality compared to traditional lung-protective ventilation. Despite being 


\title{
ReCruitment And De-Recruitment in ARDS Management
}

\begin{abstract}
based on well conducted preclinical and clinical recruitment maneuver studies, the higher mortality associated with the open-lung ventilation strategy requires re-examining the assumptions and conclusions drawn from those previous studies. This narrative review examines the evidence used to design recruitment maneuver strategies. We also review the radiologic, rheologic, and histopathologic evidence regarding the nature of lung injury and the phenomena of recruitment and de-recruitment as it informs our perceptions of recruitment potential in ARDS. Major lungprotective ventilation clinical trial data and other clinical data are also examined to assess the practical necessity of recruitment maneuvers in ARDS and whether a subset of cases might benefit from pursuing recruitment maneuver therapy. Finally, a less a radical approach to recruitment maneuvers is offered that might achieve the goals of recruitment maneuvers with less risk of harm. Key words: acute respiratory distress syndrome; alveolar recruitment maneuver; intra-abdominal pressure; plateau pressure; positive end-expiratory pressure; threshold opening pressure; ventilator-induced lung injury. [Respir Care 2021;66(3):510-530. (C) 2021 Daedalus Enterprises]
\end{abstract}

\section{Introduction}

ARDS is characterized by altered permeability, pulmonary edema, and decreased gas volume (ie, functional residual capacity [FRC]), which leads to low respiratory system compliance $\left(\mathrm{C}_{\mathrm{RS}}\right)$ and hypoxemia both from intrapulmonary shunting and ventilation-perfusion mismatching. ${ }^{1-3}$ Causes of decreased FRC include underinflated, unstable alveoli vulnerable to collapse and atelectatic or de-recruited alveoli. ${ }^{4}$ With the advent of low-tidal volume lung-protective ventilation (LPV), alveolar de-recruitment is exacerbated despite moderate levels of PEEP (ie, $10 \pm 4 \mathrm{~cm} \mathrm{H}_{2} \mathrm{O}$ ). ${ }^{5}$

Recruitment maneuvers reverse lung collapse in ARDS by applying high airway pressures that overcome a range of threshold opening pressures (TOP). Re-opening collapsed or obstructed peripheral airways and alveoli often improves oxygenation and $\mathrm{C}_{\mathrm{RS}}$, and may enhance alveolar fluid clearance. ${ }^{6-10}$ Historically, recruitment maneuvers consisted of inflations of $40 \mathrm{~cm} \mathrm{H}_{2} \mathrm{O}$ sustained for $\sim 15 \mathrm{~s}$ (ie, the force needed to achieve vital capacity in normal subjects) to reverse intraoperative atelectasis and intrapulmonary shunting. ${ }^{11,12}$

Recruitment maneuvers as an adjunct to LPV were first described in early preclinical studies of high-frequency oscillatory ventilation for acute lung injury. ${ }^{13}$ In the early 1990s, recruitment maneuvers became a central feature of a LPV variant known as open-lung ventilation (OLV). ${ }^{14,15}$ One such technique described brief periods (eg, $10 \mathrm{~min}$ ) of continuous mechanical ventilation at a peak airway

\footnotetext{
Mr Kallet and Mr Burns are affiliated with the Respiratory Care Division, Department of Anesthesia and Perioperative Care, University of California San Francisco at San Francisco General Hospital, San Francisco, California. Dr Lipnick is affiliated with the Critical Care Division, Department of Anesthesia and Perioperative Care, University of California San Francisco at San Francisco General Hospital, San Francisco, California.
}

Supplementary material related to this paper is available at http://www. rcjournal.com. pressure of $55 \mathrm{~cm} \mathrm{H}_{2} \mathrm{O}$ and PEEP of $16 \mathrm{~cm} \mathrm{H}_{2} \mathrm{O} .{ }^{14}$ Over the intervening years, the mechanics, physiology, and efficacy of recruitment maneuvers were explored in numerous clinical and preclinical studies using a variety of strategies, as well as theoretical treatises. ${ }^{16}$

Some of these findings informed the largest multi-center randomized controlled trial of OLV, the Alveolar Recruitment for Acute Respiratory Distress Syndrome Trial (ART) ${ }^{17}$ which enrolled $>1,000$ subjects with moderate to severe ARDS. Despite the data-driven protocol, the ART group ${ }^{17}$ reported significantly higher mortality in the OLV treatment arm compared to the control arm using the National Institutes of Health ARDS Clinical Trials Network (ARDSNet) lower-PEEP protocol. ${ }^{18}$ Particularly vexing was that, despite significantly higher oxygenation and $C_{R S}$ in subjects treated with OLV, the need for rescue therapies was not different. This suggests that recruitment maneuvers were largely ineffective in stabilizing FRC. Higher mortality in the OLV arm confirmed one of the major findings of the original ARDSNet LPV trial: improved oxygenation is not necessarily a valid signifier for meaningful outcomes. ${ }^{18}$

Some have interpreted the ART results to suggest abandoning recruitment maneuvers in treating ARDS, ${ }^{19}$ whereas others ${ }^{20}$ suggest that ART-related methodological issues still cloud its interpretation and have instead advocated for a thorough post hoc analysis (which, to our knowledge, has not yet been published). Furthermore, the dramatic failure of a trial based upon numerous well-executed physiologic studies behooves re-examining the nature of recruitment and de-

\footnotetext{
Mr Burns presented a version of this paper at AARC Congress 2018, held December 4-7, 2018, in Las Vegas, Nevada.

Mr Kallet has disclosed a relationship with Nihon Kohden. The remaining authors have disclosed no conflicts of interest.

Correspondence: Richard H Kallet MSc RRT FAARC. E-mail: richkallet@gmail.com.
}

DOI: $10.4187 /$ respcare. 08280 


\section{ReCruitment AND De-Recruitment in ARDS Management}

Table 1. Different Recruitment Maneuver Strategies for the Treatment of Moderate to Severe ARDS

\begin{tabular}{|c|c|}
\hline Maneuver & Description \\
\hline Sustained inflation & $\begin{array}{l}\text { CPAP is increased in } 5 \mathrm{~cm} \mathrm{H}_{2} \mathrm{O} \text { steps every } 5-10 \mathrm{~s} \text { until a target recruitment pressure of } 30-50 \mathrm{~cm} \mathrm{H}_{2} \mathrm{O} \text { is } \\
\text { achieved, and then sustained for } 30-40 \mathrm{~s} \text {. Deflation is achieved with the same stepwise decrement in airway } \\
\text { pressure until CPAP reaches baseline PEEP level (or a new targeted baseline). } \\
\text { The technique is based upon numerous clinical and preclinical studies. }\end{array}$ \\
\hline Intermittent sighs & $\begin{array}{l}\text { 1-3 programmed, consecutive sigh breaths/min targeting a } \mathrm{P}_{\text {plat }} \text { of } 35-45 \mathrm{~cm} \mathrm{H}_{2} \mathrm{O} \text {. } \\
\text { The technique is based upon small clinical studies. }\end{array}$ \\
\hline $\begin{array}{l}\text { Intermittent PEEP/“fluctuating” } \\
\text { PEEP }\end{array}$ & $\begin{array}{l}\text { Programmed, consecutive breaths in which PEEP is elevated from baseline to a higher level for either a specific } \\
\text { number of breaths/min (1-3), every few minutes or for an extended time period (6 min). } \\
\text { The technique is based on several preclinical studies without a targeted } \mathrm{P}_{\text {plat }} \text { and a case report with a targeted } \mathrm{P}_{\text {plat }} \\
\text { of } 50 \mathrm{~cm} \mathrm{H}_{2} \mathrm{O} \text { in ARDS and abdominal compartment syndrome. }\end{array}$ \\
\hline $\begin{array}{l}\text { Brief recruitment maneuver on } \\
\text { CMV }\end{array}$ & $\begin{array}{l}\text { Volume or pressure control ventilation producing a } \mathrm{P}_{\text {plat }} \text { of } 45 \mathrm{~cm} \mathrm{H}_{2} \mathrm{O} \text { at PEEP of } 15 \mathrm{~cm} \mathrm{H}_{2} \mathrm{O} \text {. } \\
\text { The technique is based on several clinical studies on the physiologic effects of recruitment maneuver. }\end{array}$ \\
\hline $\begin{array}{l}\text { Prolonged recruitment } \\
\text { maneuver }\end{array}$ & $\begin{array}{l}\text { Repeated periodic ( } 2 \mathrm{~min} \text { ) PEEP elevation to } 15 \mathrm{~cm} \mathrm{H}_{2} \mathrm{O} \text { upon which the } \mathrm{P}_{\text {plat }} \text { was then increased step-wise from } \\
30,35 \text {, and } 40 \mathrm{~cm} \mathrm{H}_{2} \mathrm{O} \text { during successive } 2 \text {-min maneuvers. } \\
\text { The technique is based on a preclinical study. }\end{array}$ \\
\hline $\begin{array}{l}\text { Slow moderate pressure recruit- } \\
\text { ment maneuver }\end{array}$ & $\begin{array}{l}\text { PEEP is increased to } 15 \mathrm{~cm} \mathrm{H}_{2} \mathrm{O} \text { for } 15 \mathrm{~min} \text { at a } \mathrm{V}_{\mathrm{T}} \text { of } 10 \mathrm{~mL} / \mathrm{kg} \text { (producing a } \mathrm{P}_{\text {plat }} \text { of } \sim 27 \mathrm{~cm} \mathrm{H}_{2} \mathrm{O} \text { ), and a } 7-\mathrm{s} \\
\text { end-inspiratory pause is applied every } 30 \mathrm{~s} \text {. } \\
\text { The technique is based on a preclinical study. }\end{array}$ \\
\hline Extended sigh & $\begin{array}{l}\text { Two approaches: } \\
\text { 1) PEEP is increased to } 10 \mathrm{~cm} \mathrm{H}_{2} \mathrm{O} \text { above LIP and } \mathrm{P}_{\text {plat }}<\text { upper inflection point; if upper } \\
\text { inflection point is unidentifiable, then } \mathrm{V}_{\mathrm{T}} \text { is adjusted to maintain } \mathrm{P}_{\text {plat }} \leq 35 \mathrm{~cm} \mathrm{H}_{2} \mathrm{O} \text { for } 15 \text { min. } \\
\text { 2) PEEP is increased stepwise }\left(5 \mathrm{~cm} \mathrm{H} \mathrm{H}_{2} \mathrm{O} \text { every } 30 \mathrm{~s}\right) \text { while } \mathrm{V}_{\mathrm{T}} \text { is reduced in 2-mL/kg steps until reaching a PEEP } \\
\text { of } 25 \mathrm{~cm} \mathrm{H}_{2} \mathrm{O} \text { and a } \mathrm{V}_{\mathrm{T}} \text { of } 2 \mathrm{~mL} / \mathrm{kg} \text {; this is followed by CPAP at } 30 \mathrm{~cm} \mathrm{H}_{2} \mathrm{O} \text { and then a deflationary phase } \\
\text { pattern to return to baseline settings or to PEEP set } 2 \mathrm{~cm} \mathrm{H}_{2} \mathrm{O} \text { above the lower inflection point. } \\
\text { The technique is based upon several small clinical studies. }\end{array}$ \\
\hline RAMP recruitment maneuver & $\begin{array}{l}\text { Two approaches: } \\
\text { 1) CPAP is increased } 1 \mathrm{~cm} \mathrm{H}_{2} \mathrm{O} / \mathrm{s} \text { to reach } 40 \mathrm{~cm} \mathrm{H}_{2} \mathrm{O} \text {. } \\
\text { 2) Peak inspiratory pressure and PEEP increased simultaneously } 1-2 \mathrm{~cm} \mathrm{H} \mathrm{H}_{2} \mathrm{O} \text { every 2-3 min. Criteria to stop open } \\
\text { lung are based on reaching oxygenation goals at } \mathrm{F}_{\mathrm{IO}_{2}} \leq 0.25 \text { (neonatal model). } \\
\text { The technique is based on a preclinical study. }\end{array}$ \\
\hline Staircase recruitment maneuver & $\begin{array}{l}\text { Pressure control ventilation with a fixed driving pressure of } 15 \mathrm{~cm} \mathrm{H}_{2} \mathrm{O} \text { starting at a PEEP of } 25 \mathrm{~cm} \mathrm{H}_{2} \mathrm{O} \text {. This } \\
\text { strategy uses 2-min periods of alternating increasing and decreasing incremental PEEP steps that ramp up from } \\
5 \text { to } 10 \text { and to } 15 \mathrm{~cm} \mathrm{H}_{2} \mathrm{O} \text { to achieve a } \mathrm{P}_{\text {plat }} \text { of } 60 \mathrm{~cm} \mathrm{H}_{2} \mathrm{O} \text {. } \\
\text { Post-recruitment maneuver PEEP is set according to a decremental trial with optimum PEEP defined as the level } \\
\text { just above the threshold when deterioration in either oxygenation or compliance is observed. } \\
\text { Several iterations of this general approach exist using different maximum levels of PEEP and } \mathrm{P}_{\text {plat }} \text { (eg, } 25 \text { and } 45- \\
50 \mathrm{~cm} \mathrm{H}_{2} \mathrm{O} \text {, respectively. } \\
\text { The technique is based upon multiple small and large clinical studies as well as preclinical studies. }\end{array}$ \\
\hline $\begin{array}{l}\mathrm{P}_{\text {plat }}=\text { plateau pressure } \\
\mathrm{CMV}=\text { continuous mechanical ventilation } \\
\mathrm{V}_{\mathrm{T}}=\text { tidal volume }\end{array}$ & \\
\hline
\end{tabular}

recruitment as well as the validity of inferences drawn from them. This narrative review re-examines the physiology and mechanics of recruitment and de-recruitment in ARDS, the results of which might suggest when and how recruitment maneuvers might be incorporated more reasonably into clinical practice.

\section{Brief Overview of Recruitment Maneuvers in ARDS}

Different approaches to recruitment maneuvers have been developed over the past 30 years (Table 1). One of the earliest and most popular strategies has been the sustained inflation maneuver using CPAP. ${ }^{15,21-24}$ Another strategy (ie, amplitude-modulated ventilation) posited that following a deep inflation the time constants for alveolar closure (of previously collapsed units) were substantially longer than the ventilatory cycle, so that recruitment achieved from a single deep inflation (or short periods of elevated PEEP) could be sustained for a period of time afterwards. ${ }^{25,26}$ This was hypothesized to allow alveolar stabilization without requiring sustained levels of higher PEEP. Strategies based on this approach include intermittent sigh breaths ${ }^{27,28}$ and 


\section{ReCruitment AND De-Recruitment in ARDS Management}

intermittent or fluctuating PEEP. ${ }^{29-31}$ Another approach is a less intense variation of the recruitment maneuver technique described by Lachmann, ${ }^{14}$ in which a brief $(2 \mathrm{~min})$ period of ventilation at a plateau pressure $\left(\mathrm{P}_{\text {plat }}\right)$ of $45 \mathrm{~cm}$ $\mathrm{H}_{2} \mathrm{O}$ and PEEP of $15 \mathrm{~cm} \mathrm{H}_{2} \mathrm{O}$ is used. ${ }^{32}$ Other, more extended iterations of this approach include the prolonged recruitment maneuver ${ }^{33}$ and the slow moderate pressure recruitment maneuver. ${ }^{34}$ Other prolonged approaches include the extended sigh maneuver ${ }^{35-37}$ and the RAMP technique. ${ }^{38,39}$ These last 4 techniques most closely resemble what is currently the most widely investigated technique (and the primary focus of this review): the staircase recruitment maneuver. ${ }^{40}$ The impact of these techniques will be discussed in varying detail throughout the course of this review in terms of what they reveal about the nature of recruitment in ARDS.

Recruitment maneuver studies have categorized ARDS subjects as either responders or nonresponders according to the presence and magnitude of improvement in oxygenation, ${ }^{26}$ resting lung volume, ${ }^{26}$ or reduction in nonaerated lung tissue by computed tomography (CT) scan, electrical impedance tomography, or ultrasonography. ${ }^{34,41}$ This implies recruitment maneuvers have a limited application under specific conditions not always discernable at the bedside. ARDS associated with either direct epithelial injury (ie, pulmonary or primary ARDS) or indirect endothelial injury (ie, extrapulmonary or secondary ARDS) both demonstrate improved oxygenation following the maneuver: those with indirect injury tended to be more responsive both in the degree of recruitment and oxygenation and of reductions in both lung resistance and elastance. ${ }^{21,27,42}$ Indirect injury typically coincides with early interstitial edema and higher chest wall elastic forces, ${ }^{43,44}$ suggesting that recruitment maneuvers are most effective when compressive and congestive atelectasis are major factors versus alveolar flooding and tissue consolidation, which are more prominent in direct injury such as pneumonia (see below).

\section{Physics and Physiology of Recruitment: Pressure and Time}

The focus of recruitment has been on alveolar reinflation. This is a matter of conversational convenience that unintentionally results in an underappreciation of the fact that distal airway injury and inflammation is a prominent feature of ARDS and cannot be separated from alveolar injury. ${ }^{45}$ What follows is a description of the interplay between distal airway and alveolar injury as it relates to recruitment phenomena. In a later section describing the ambiguities surrounding recruitment maneuvers, a more in-depth description of associated tissue-related factors (ie, rheology and histopathology) will be provided.
Injury in distal airways (ie, airways with a diameter $<2$ $\mathrm{mm}$ ) in ARDS is characterized by bronchiolar epithelial necrosis/sloughing and the rupturing of bronchiolar-alveolar attachments that promotes distal airway instability. ${ }^{45,46}$ This in turn increases airways resistance and expiratory flow limitation. ${ }^{2,47}$ Opening collapsed small airways in ARDS is a dynamic process with a variable time course that depends upon several factors, including airway radius, the fraction of functional alveoli providing regional airway stability (ie, axial wall traction or tethering), airway fluid characteristics (ie, surface tension and viscous forces, as well as film thickness) and the presence of biologically active surfactant. ${ }^{48-51}$ As lining fluid surface tension increases, so too does the TOP to overcome it, with additional pressure required to overcome viscous forces. As airway fluid viscosity increases, both yield pressure and time required to effect airway opening also increase, which may be particularly difficult to achieve in peripheral and terminal airways. ${ }^{50}$

Regarding normal alveolar response to recruitment, an experimental microimaging study of deflated healthy lungs undergoing stepwise inflation from 0 to $35 \mathrm{~cm} \mathrm{H}_{2} \mathrm{O}$ observed an unusual U-shaped pattern, whereby mean alveolar size first increased, stabilized (at $25 \mathrm{~cm} \mathrm{H}_{2} \mathrm{O}$ ), and then decreased. The number of inflated alveoli decreased and then markedly increased again at pressures of $25-35 \mathrm{~cm}$ $\mathrm{H}_{2} \mathrm{O}$, causing a doubling of lung volume size. ${ }^{52}$ In other words, at higher pressures, alveoli paradoxically become both smaller and more plentiful. It was hypothesized that stretching the alveolar wall increases the diameter of the pores of Kohn. This in turn thins the alveolar lining fluid normally covering the pores, thus facilitating pressure transmission between adjacent mother-daughter alveoli and resulting in the latter's recruitment.

These experimental conditions, however, diverge from those encountered in ARDS such that similar behavior (if it in fact occurs during a recruitment maneuver) might require a prolonged time period. In early ARDS altered permeability pulmonary edema fluid contains protein concentrations similar to plasma. ${ }^{53,54}$ Protein and fibrin-rich alveolar edema, along with oxygen radicals, inactivates surfactant, resulting in higher TOP for both distal airways and alveoli. ${ }^{55}$

Depending upon the severity of pulmonary capillary leakage, when alveolar flooding involves the alveolar ducts, liquid bridge formation rises exponentially, particularly when FRC decreases and elastic recoil forces increase. ${ }^{56}$ Bronchiolar epithelial damage and inflammation also are present and associated with ARDS severity, ${ }^{45,57}$ thereby increasing the likelihood of inflammatory exudate obstructing both the airway lumen and the pores of Kohn. Because fluid viscosity increases with increasing protein concentrations, ${ }^{58}$ enhanced viscosity of airway and alveolar lining fluid (along with other cellular debris accumulating in the peripheral airspaces) may prolong the time necessary to 


\section{Recruitment And De-Recruitment in ARDS Management}

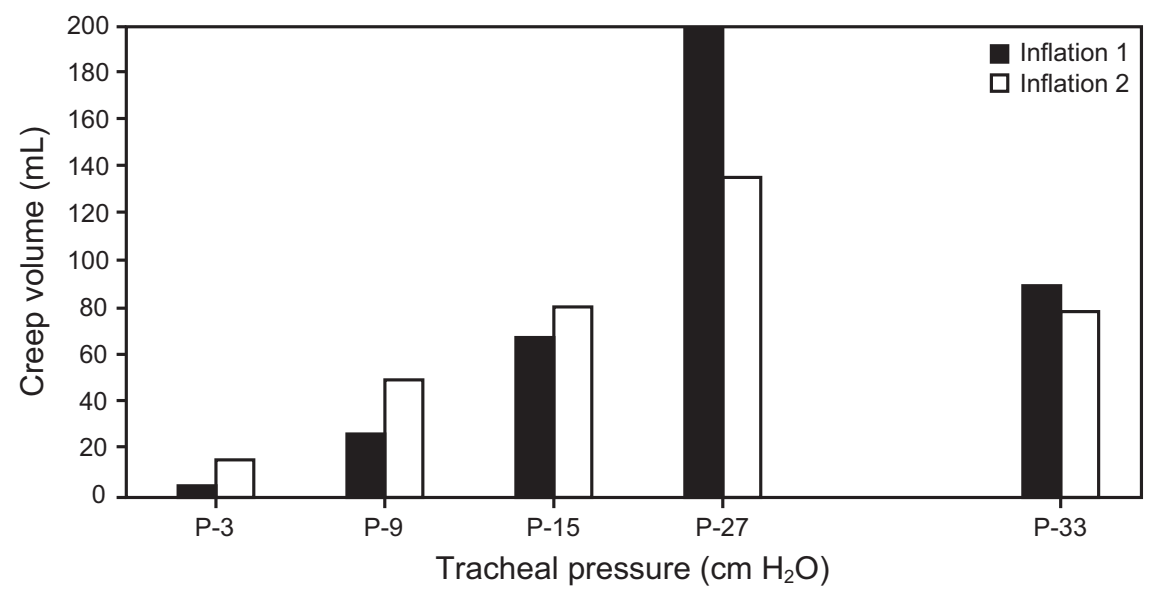

Fig. 1. Association between increasing driving pressures and alveolar stress adaptation in an animal model with normal chest mechanics. Data from Reference 60.

achieve maximum recruitment for any targeted $\mathrm{P}_{\text {plat }}$ during a recruitment maneuver.

The time necessary to reopen collapsed or obstructed small airways also depends upon the extent of menisci formation or plugs in sequentially collapsed or obstructed airways, which may be amplified either by the presence of mucus in pneumonia-associated ARDS or in patients with substantial smoking histories. ${ }^{48,50,59}$ In other words, the level of recruitment reported at a specific $\mathrm{P}_{\text {plat }}$ cited in recruitment maneuver studies that were sustained for 1-2 min is not definitive proof of maximum efficacy at that level of applied pressure (see below).

\section{Temporal Aspects of Lung Recruitment}

Two temporal aspects influence the effectiveness of recruitment: (1) the duration of any particular recruitment maneuver itself, and (2) the clinician-set inspiratory time chosen during the maneuver. Some of what is discussed below reflects this ambiguity as to precisely what occurs when we observe recruitment. Some of this (but by no means all) has been clarified by the advent of lung parenchymal microimaging in animal models, as discussed above. The following 2 sections provide a historical narrative on the development of our understanding as well as the persistent ambiguity surrounding recruitment from the 1960s to the 1990s.

\section{Creep: Fast Versus Slow Pulmonary Compartments}

The term "creep" was coined in the 1960s to describe the progressive increase in volume over time when the lungs are subjected to "constant" pressure inflations. ${ }^{60,61}$ More broadly referred to as hysteresis or stress adaptation, creep expresses how tissue, once deformed, resists returning to its former shape. This is attributed to adaptive surface tension forces in the lungs and intrinsic viscoelastic properties of both lung and chest wall tissue (eg, the presence of elastic fibers in smooth muscle, skeletal muscle, ligaments, and tendons) as well as abdominal organs. ${ }^{61}$

Under normal physiology, a 2-phase process consisting of fast and slow compartments was described in animals. ${ }^{60}$ During a 10 -s inflation hold, an initial rapid (2 s) phase is followed by a slow (8 s) phase of continued tissue stretching; the latter was attributed primarily to alveolar recruitment and reduced alveolar surface tension, and to a lesser degree alterations in tissue viscoelastic properties. ${ }^{62}$ Stress adaptation was directly associated with increasing driving pressures and reaching maximum creep at $33 \mathrm{~cm} \mathrm{H}_{2} \mathrm{O}$. Increasing sustained inflation intensity (ie, $120 \mathrm{~s}$ at 33 and $39 \mathrm{~cm} \mathrm{H}_{2} \mathrm{O}$ ) effected additional stress adaptation (Fig. 1) ${ }^{60}$

Stress adaptation has been observed in anesthetized normal subjects undergoing step inflations (similar to constructing a pressure-volume curve), stabilizing at 5-7 s at different volumes. ${ }^{61}$ Two thirds of stress adaptation was attributed to the lungs, with the chest wall exhibiting a smaller, slower time course. This was ascribed to tissue properties in both structures rather than alveolar recruitment and gas redistribution. ${ }^{61}$

\section{Evidence Supporting Creep Phenomenon in ARDS}

In ARDS, slow volume changes following a $10 \mathrm{~cm} \mathrm{H}_{2} \mathrm{O}$ PEEP increase were first reported by Katz et al, ${ }^{4}$ whereby $67 \%$ of volume change occurred during the first breath and $90 \%$ by the fifth breath. The remaining increase occurred over $40 \mathrm{~min}$ and was attributed either to stress adaptation or alveolar recruitment. Similar to other findings,${ }^{61} 62 \%$ of the changes were attributed to the lungs and $38 \%$ to the chest wall. $^{4}$ 


\section{ReCruitment AND De-Recruitment in ARDS Management}

Slowly distensible pulmonary compartments in severe ARDS have been reported by others. ${ }^{63}$ Using a $5 \mathrm{~cm} \mathrm{H}_{2} \mathrm{O}$ PEEP increment, only $37 \%$ of subjects exhibited a slow recruitment compartment, whereas $79 \%$ displayed a slow de-recruitment compartment, consistent with other studies reporting delayed de-recruitment following step-decreases in PEEP. ${ }^{26}$ The mean inflation time constant $(\tau)$ of the slow compartment was $9.4 \pm 7.3 \mathrm{~s}$. As $95 \%$ equilibration occurs at $3 \tau$ and $99 \%$ at $5 \tau,{ }^{64}$ recruitment (or stress adaptation) of slow pulmonary compartments would reach $95-99 \%$ volume equilibration at mean times of $28-47 \mathrm{~s}$ with an upper $95 \%$ confidence limit of 43-72 s. As a reference, in normal subjects under general anesthesia, atelectasis reversal occurs at $\tau$ of $2.6 \mathrm{~s}(95-99 \%$ reversal at $8-13 \mathrm{~s}){ }^{12}$

In contrast, when oxygenation is the variable of interest, the temporal impact on recruitment is exaggerated. Several studies examined the time required to establish steady state oxygenation in ARDS following a PEEP increase or after initiating sigh breaths. ${ }^{27,65,66}$ Setting PEEP above the lower inflection point (PEEP $14 \pm 3 \mathrm{~cm} \mathrm{H}_{2} \mathrm{O}$ ), $90 \%$ of maximal improvement occurred at $20 \pm 19 \mathrm{~min} .{ }^{65}$ However, in another study, a $10 \mathrm{~cm} \mathrm{H}_{2} \mathrm{O}$ PEEP increase produced no apparent oxygenation plateau (ie, $\mathrm{P}_{\mathrm{aO}_{2}}$ progressively increased by $5-60 \mathrm{~min}) .{ }^{66}$ When augmenting LPV with intermittent sigh breaths $\left(\mathrm{P}_{\text {plat }} 45 \mathrm{~cm} \mathrm{H}_{2} \mathrm{O}\right.$; PEEP $14 \mathrm{~cm}$ $\mathrm{H}_{2} \mathrm{O}$ ) maximum improvements occurred at $30 \mathrm{~min}$ for both $\mathrm{P}_{\mathrm{aO}}$ and end-expiratory lung volume. ${ }^{27}$

An intriguing aspect of recruitment are transient (pulmonary) states observed in ARDS when the ventilatory pattern was altered. ${ }^{67}$ Prolonged effects of recruitment were noted after various manipulations, including a single PEEP step, a PEEP wave maneuver, and an undulating PEEP pattern. One hour following a PEEP increase from 13 to $21 \mathrm{~cm} \mathrm{H}_{2} \mathrm{O}$, FRC rose $150 \%$ greater than that predicted by $\mathrm{C}_{\mathrm{RS}}$ of the fast pulmonary compartment (ie, baby lung). ${ }^{68}$ These results were similar to those reported by Katz et al. ${ }^{4}$

In the PEEP wave study, a brief repetitive cycle of incremental ascending and descending PEEP with a maximum PEEP change of $10 \mathrm{~cm} \mathrm{H}_{2} \mathrm{O}$ was repeated 5 times over several hours. When PEEP was returned to the initial settings, $\mathrm{P}_{\mathrm{aO}}$ stabilized at $10 \mathrm{~mm} \mathrm{Hg}$ above the previous baseline. The phenomenon occurred with each successive PEEP wave so that, at the end of the experimental run, $\mathrm{P}_{\mathrm{aO}}$ was $80 \mathrm{~mm} \mathrm{Hg}$ higher than at the initial baseline. ${ }^{67}$

The undulating PEEP study assessed the upper limit of time constant distributions using a PEEP cycle above and below a baseline PEEP of $14 \mathrm{~cm} \mathrm{H}_{2} \mathrm{O}$. PEEP was titrated in increments of $7 \mathrm{~cm} \mathrm{H}_{2} \mathrm{O}$ up to $29 \mathrm{~cm} \mathrm{H}_{2} \mathrm{O}$ and down to 0 $\mathrm{cm}_{2} \mathrm{O}$ over $9 \mathrm{~h}$. FRC measured $1 \mathrm{~h}$ following any PEEP change did not indicate a steady state in terms of recruitment or de-recruitment. The overall impression was that "the length of individual time constants in ARDS may exist in the region of hours." ${ }^{\prime 67}$
Slow, progressive lung recruitment frequently observed during prone position therapy supports the existence of slow pulmonary compartments in ARDS. ${ }^{69}$ Initial improvement in oxygenation typically occurred within 30$60 \mathrm{~min}$, yet it is not uncommon for improvements to become apparent only after $6 \mathrm{~h}$, with continuing improvements sometimes observed over 20-36 h. ${ }^{69}$ Prolonged recruitment maneuver (ie, 6-14 h) reversing profound refractory hypoxemia has been reported anecdotally in ARDS complicated by abdominal compartment syndrome ${ }^{70}$ and in pronounced obesity when combined with prone position. ${ }^{69}$

These findings underscore the considerable difference in the time frames chosen to evaluate oxygenation response following a recruitment maneuver. Several recruitment maneuver studies that will be discussed in the next section used 2-min equilibration periods between all or some of the PEEP steps, ${ }^{17,40,71-73}$ which is consistent with classic physiologic studies. ${ }^{60,67,74}$ While the 2-min limit allows for stress adaptation, it also limits exposure to severe respiratory acidemia $^{40}$ and potential cardiovascular instability from alterations in right and left ventricular function. ${ }^{75-78}$ Most importantly, these necessary time constraints imposed by very high pressure recruitment maneuver techniques limits our ability to fully understand the actual recruitment potential in ARDS.

\section{Selecting Inspiratory Time During Recruitment Maneuver}

The other temporal aspect is whether the inspiratory time per breath impacts the overall effectiveness of a recruitment maneuver. This is likely dependent upon whether the clinician-set inspiratory time is appropriate for the inspiratory time constant of individual patients. In general, ARDS subjects have an inspiratory $\tau$ of $0.17-0.41 \mathrm{~s}^{2}$, which (depending upon syndrome severity) would result in $95 \%$ and $99 \%$ estimated equilibration between airway and alveolar pressures at $\sim 0.5-1.2 \mathrm{~s}$ and $0.9-2.1 \mathrm{~s}$, respectively. However, these estimates are based on assumptions of mono-exponential functions of constant elastances and resistances throughout inspiration, and therefore neglect the impact of mechanical inhomogeneity in ARDS. ${ }^{79}$ Moreover, they ignore the impact of continued gas mixing and redistribution (ie, pendelluft motion) and increased diffusion time on both oxygenation and dead-space ventilation by which recruitment maneuver efficacy often is assessed.

The range of inspiratory time reported in recruitment maneuver studies have varied: $1.5 \mathrm{~s}$ (single PEEP step), ${ }^{63}$ $2.5 \pm 1.1 \mathrm{~s}$ (for sigh breaths), ${ }^{27} 2-3 \mathrm{~s}^{17,71,72,80}$ (for staircase recruitment maneuver studies or unspecified), ${ }^{40}$ whereas others used an end-inspiratory pause of 5-7 s. ${ }^{34,81}$ In a lung lavage model of acute lung injury, in vivo microscopic studies of subpleural alveoli during a recruitment maneuver 


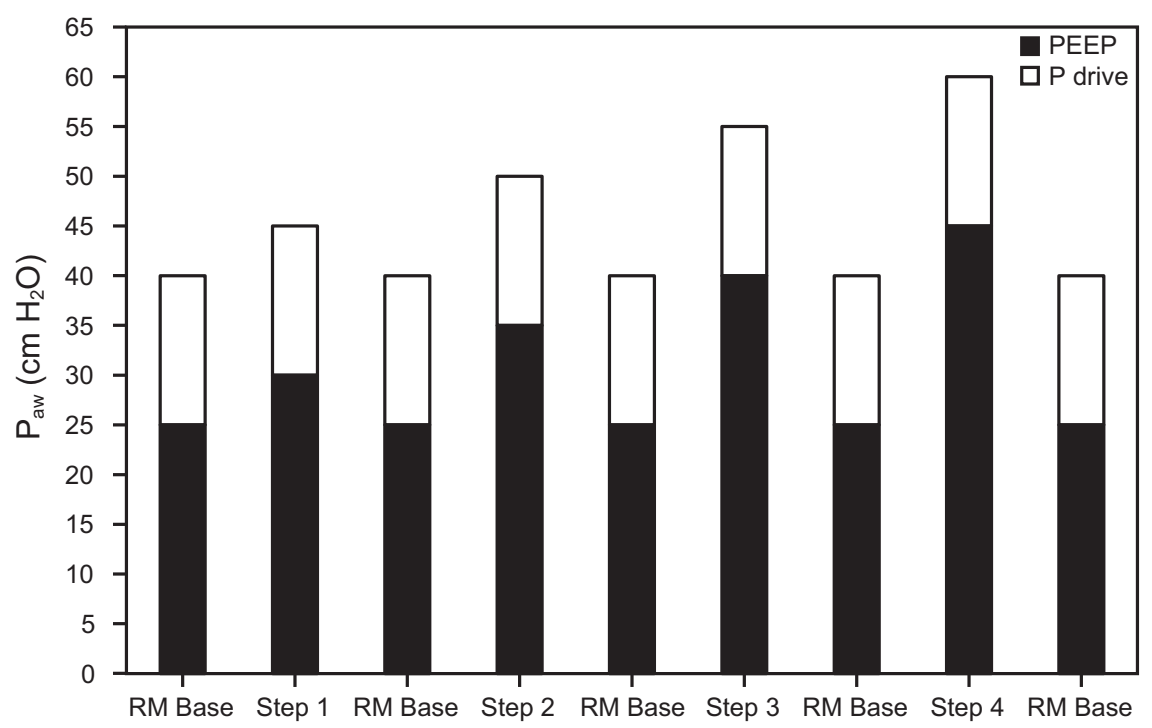

Fig. 2. Representation of a "staircase" recruitment maneuver inflation steps. $P$ drive $=$ driving pressure (plateau pressure $-P E E P) ; P a w=$ airway pressure; RM = recruitment maneuver. Data from Reference 84.

at $40 \mathrm{~cm} \mathrm{H}_{2} \mathrm{O}$ found that, over a period of $40 \mathrm{~s}, \sim 85 \%$ of recruitment occurred by $2 \mathrm{~s}^{82}$ These data support clinical use of inspiratory times of 2-3 s to maximize per-breath recruitment potential during an recruitment maneuver.

\section{Mechanics of Recruitment and De-Recruitment}

The majority of physiologic and clinical studies investigating recruitment in ARDS began in earnest in the first decade of this century and has produced the majority of our current knowledge base and clinical evidence. Because of this, the narrative in this section mostly derives from select studies we believe constitute the most important findings regarding recruitment maneuver and PEEP titration informing current practice.

In 2000, a variant of the original recruitment maneuver used in OLV, ${ }^{14}$ was introduced by Medoff et $a l,{ }^{83}$ who applied pressure control ventilation at a $\mathrm{P}_{\text {plat }}$ of $60 \mathrm{~cm} \mathrm{H}_{2} \mathrm{O}$ and PEEP of $40 \mathrm{~cm} \mathrm{H}_{2} \mathrm{O}$ for $2 \mathrm{~min}$. In a subsequent study comparing pressure control ventilation recruitment maneuvers to sustained inflation recruitment maneuvers (CPAP of $45 \mathrm{~cm} \mathrm{H}_{2} \mathrm{O}$ ), a 2-min trial pressure control ventilation recruitment maneuver (using a lower $\mathrm{P}_{\text {plat }}$ of $45 \mathrm{~cm} \mathrm{H}_{2} \mathrm{O}$ and inspiratory time of $2.5 \mathrm{~s}$ ) produced substantially greater oxygenation improvement ( $80 \%$ vs $19 \%)^{75}$

Since the case report by Medoff et al, ${ }^{83}$ the pressure control ventilation recruitment maneuver has become a popular approach and was the basis of the strategy used in the ART trial. ${ }^{17} \mathrm{~A}$ generalized description of this approach is as follows: an initial $\mathrm{P}_{\text {plat }}$ of $40 \mathrm{~cm} \mathrm{H}_{2} \mathrm{O}$ is slowly increased in increments of $5 \mathrm{~cm} \mathrm{H}_{2} \mathrm{O}$ to levels of 50 or $60 \mathrm{~cm} \mathrm{H}_{2} \mathrm{O}$. The recruitment maneuver is done using 2-3 min stepwise escalation/de-escalation of super-PEEP (ie, 20-45 $\mathrm{cm} \mathrm{H}_{2} \mathrm{O}$ ) with a fixed driving pressure (ie, the difference between $\mathrm{P}_{\text {plat }}$ and PEEP) of $15 \mathrm{~cm} \mathrm{H}_{2} \mathrm{O}$ (Fig. 2). ${ }^{40,84}$ This is based on observations that TOP ( $\mathrm{P}_{\text {plat }}$ being the clinical correlate) progressively increases from nondependent to dependent lung between $20-60 \mathrm{~cm} \mathrm{H}_{2} \mathrm{O}^{40,85}$ A variation of this technique was used in the ART trial but with stabilization periods of only 1 or 2 min between steps (Fig. 3). ${ }^{17}$

When absorption atelectasis is pervasive, $\mathrm{P}_{\text {plat }}$ up to 70 $\mathrm{cm} \mathrm{H}_{2} \mathrm{O}$ is required, ${ }^{85}$ and pressures up to $80 \mathrm{~cm} \mathrm{H}_{2} \mathrm{O}$ have been used in ARDS associated with blunt chest trauma ${ }^{86}$ or abdominal compartment syndrome. ${ }^{70}$ To place these extraordinary pressures into perspective, the first few post-natal breaths, which expand gasless, partially liquid-filled lungs (ie, 100 times more viscous than air), require TOP of $40 \mathrm{~cm}$ $\mathrm{H}_{2} \mathrm{O}$ and peak transpulmonary pressures of $60-100 \mathrm{~cm}$ $\mathrm{H}_{2} \mathrm{O}$ to achieve full inflation. ${ }^{87,88}$ The unique circumstances in the moments following birth, in which completely deflated, non-injured lungs are initially expanded, are markedly different from that of heterogenous lung and distal airway injury present in ARDS (in addition to pathological alterations in chest wall mechanics). Nonetheless, the physics illustrates the circumstantial necessity that sometimes requires applying extraordinarily high transpulmonary pressures to displace liquid and re-expand the lungs under extreme conditions.

\section{Distribution of TOP and Recruitment}

Small physiologic studies suggest varying degrees of recruitment occur throughout the lung. An early CT study reported that potentially recruitable lung in moderate-tosevere ARDS averaged $21 \pm 10 \%$ and required a $\mathrm{P}_{\text {plat }}$ of 45 $\mathrm{cm} \mathrm{H}_{2} \mathrm{O}$ (whereas $\sim 25 \%$ remained collapsed) ${ }^{80}$ Also, 


\section{ReCruitment And De-ReCruitment in ARDS Management}

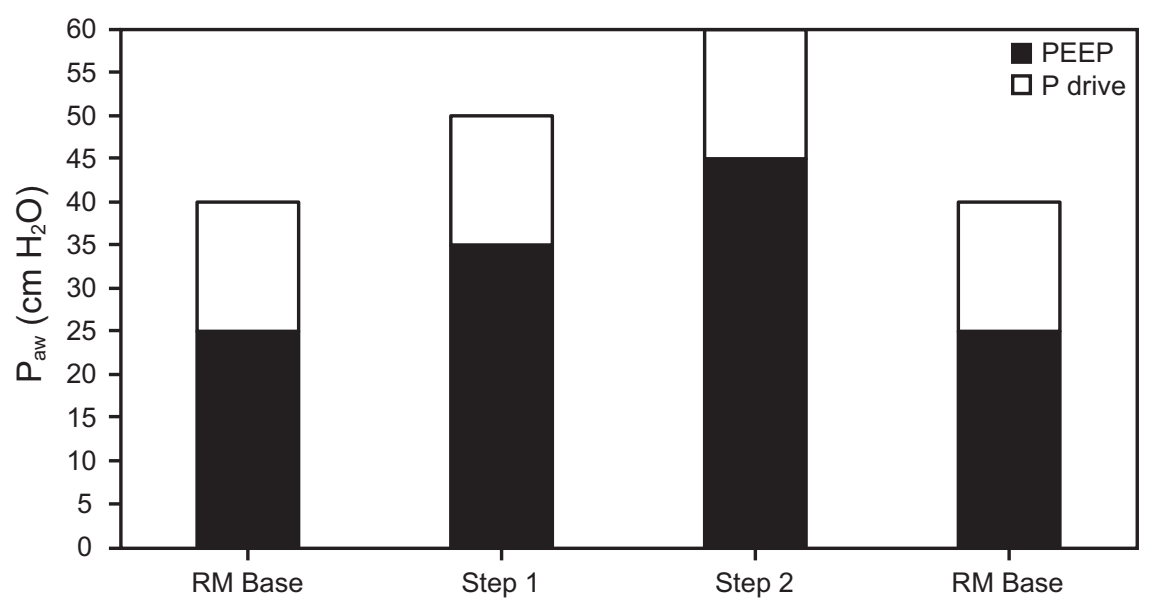

Fig. 3. Representation of a "staircase" recruitment maneuver inflation steps as used initially during the ART trial. P drive $=$ driving pressure (plateau pressure - PEEP); $\mathrm{P}_{\mathrm{aw}}=$ airway pressure; $\mathrm{RM}=$ recruitment maneuver. Data from Reference 17.

there may exist nodal points whereby full recruitment transitions down the lungs from mid-to-dorsal regions when $\mathrm{P}_{\text {plat }}$ of 30,35 , and $45 \mathrm{~cm} \mathrm{H}_{2} \mathrm{O}$ are reached (with the least amount of nonaerated tissue observed at $\left.45 \mathrm{~cm} \mathrm{H}_{2} \mathrm{O}\right){ }^{40,85}$ Subsequent studies have reaffirmed that TOP varies down the ventral-dorsal axis in ARDS. Upper zones had a negligible TOP of $0-4 \mathrm{~cm} \mathrm{H}_{2} \mathrm{O}$, whereas middle zones had a TOP of 4-7 cm $\mathrm{H}_{2} \mathrm{O}$ and dorsal lung recruitment commenced at $\sim 20 \mathrm{~cm} \mathrm{H}_{2} \mathrm{O} .{ }^{81}$

Similar to initial post-natal breaths, achieving a TOP in ARDS is not synonymous with full recruitment. Early pressure-volume curve studies of ARDS interpreted the lower inflection point as the TOP needed to recruit collapsed peripheral airways and alveoli, but it was misconstrued as the anchoring point for setting best PEEP. ${ }^{89}$ It later became apparent that recruitment merely commenced in the upper lung zones at the lower inflection point and continued throughout the inspiratory pressurevolume limb. ${ }^{90,91}$ Likewise, despite TOPs of $4-7 \mathrm{~cm}$ $\mathrm{H}_{2} \mathrm{O}$ (middle) and $\sim 20 \mathrm{~cm} \mathrm{H}_{2} \mathrm{O}$ (dorsal), maximum recruitment in these regions occurs at $20-30 \mathrm{~cm} \mathrm{H}_{2} \mathrm{O}$ and $45 \mathrm{~cm} \mathrm{H}_{2} \mathrm{O}$, respectively. ${ }^{81,85}$

Other CT imaging studies reported that nonaerated lung tissue progressively decreased from $55 \%$ (at a baseline ventilation with $10 \mathrm{~cm} \mathrm{H}_{2} \mathrm{O}$ of PEEP) to $23 \%$ at a $\mathrm{P}_{\text {plat }}$ of 40 $\mathrm{cm} \mathrm{H}_{2} \mathrm{O}$ and to $10 \%$ at a $\mathrm{P}_{\text {plat }}$ of $50 \mathrm{~cm} \mathrm{H}_{2} \mathrm{O} .{ }^{71}$ Improved recruitment was observed even when $\mathrm{P}_{\text {plat }}$ increased from a baseline of $28-32 \mathrm{~cm} \mathrm{H}_{2} \mathrm{O}$ to $36-41 \mathrm{~cm} \mathrm{H}_{2} \mathrm{O}$ at essentially the same PEEP level. ${ }^{5}$ Most importantly (in light of the ART study results), extending a recruitment maneuver to a $\mathrm{P}_{\text {plat }}$ of $60 \mathrm{~cm} \mathrm{H}_{2} \mathrm{O}$ only reduced nonaerated tissue by $5 \%$. Full recruitment has been reported at $\mathrm{P}_{\text {plat }}$ of $40-51 \mathrm{~cm}$ $\mathrm{H}_{2} \mathrm{O},{ }^{72}$ whereas others have reported increasing percentages of subjects achieving full recruitment as $\mathrm{P}_{\text {plat }}$ increased: $46 \%$ at $40 \mathrm{~cm} \mathrm{H}_{2} \mathrm{O}, \sim 60 \%$ at $45 \mathrm{~cm} \mathrm{H}_{2} \mathrm{O}$, and $\sim 70 \%$ at 50 $\left.\mathrm{cm} \mathrm{H}_{2} \mathrm{O}\right) .{ }^{40}$ In the seminal study on the time course of FRC improvement with PEEP in subjects with acute respiratory failure, the majority of whom likely would have met the current definition of ARDS, a $\mathrm{P}_{\text {plat }}$ of $40 \mathrm{~cm} \mathrm{H}_{2} \mathrm{O}$ and PEEP of $18 \mathrm{~cm} \mathrm{H}_{2} \mathrm{O}$ were needed to return $\mathrm{FRC}$ to normal. ${ }^{4}$ Thus, in the context of refractory hypoxemia even at moderate to high levels of PEEP, a recruitment maneuver $\mathrm{P}_{\text {plat }}$ of at least $40 \mathrm{~cm} \mathrm{H} \mathrm{H}_{2} \mathrm{O}$ probably should be targeted.

Furthermore, there is speculation that the recruitable lung represents a penumbra of inflamed tissue surrounding a core nidus of compartmentalized injury, constituting a mixture of collapsed or partially flooded air spaces. ${ }^{21,92}$ The remaining $\sim 25 \%$ of nonaerated lung tissue, despite recruiting pressures of $45 \mathrm{~cm} \mathrm{H}_{2} \mathrm{O},{ }^{80}$ likely signifies consolidated tissue, at least in those with normal body habitus (see below).

\section{Interpretive Limitations of Mechanistic Studies of Recruitment}

Interpreting these recruitment maneuver studies raises several issues. First, confounding factors influence the potential effectiveness of recruitment maneuvers in ARDS. These may include: (1) the inherently heterogenous nature and unique spatial patterns of acute lung injury among individual patients; (2) apparent differences in the response to recruitment maneuver related either to initiating pathways (direct vs indirect, interstitial vs alveolar edema) or the severity of injury (eg, the degree of inflammation and magnitude of edema formation); (3) timing of recruitment maneuver relative to syndrome onset; (4) the ventilatory strategy used prior to initiating recruitment maneuver; (5) alterations in chest wall mechanics; and (6) hemodynamic status (eg, various vasoactive drugs that might affect cardiac output and pulmonary blood flow distribution). ${ }^{24,93-98}$ Moreover, mechanistic recruitment maneuver studies require highly complex, clinically 


\section{ReCruitment AND De-Recruitment in ARDS Management}

impractical methodologies that limit the number of subjects who can be studied and thus limits the generalizability of results to individual patients.

Second, variables chosen to signify full recruitment differed between studies, which introduces interpretative ambiguity. Borges et al ${ }^{40}$ used $\mathrm{P}_{\mathrm{aO}}+\mathrm{P}_{\mathrm{aCO}_{2}}>400 \mathrm{~mm} \mathrm{Hg}$. Adjusting for the range of mean $\mathrm{P}_{\mathrm{aCO}_{2}}$ across recruitment maneuver steps (70-95 $\mathrm{mm} \mathrm{Hg}$ ) yields a corresponding $\mathrm{P}_{\mathrm{aO}_{2}}$ of $\sim 300-330 \mathrm{~mm} \mathrm{Hg}$. Povoa et $\mathrm{al}^{72}$ used a $\mathrm{P}_{\mathrm{aO}_{2}}$ of $250 \mathrm{~mm} \mathrm{Hg}$ on an $\mathrm{F}_{\mathrm{IO}_{2}}$ of 1 , and de Matos et al ${ }^{71}$ reported the $\mathrm{P}_{\text {plat }}$ at which nonaerated alveoli was minimal. Studies by both Crotti et a ${ }^{85}$ and Caironi et $\mathrm{al}^{92}$ merely reported the degree of recruitment observed at a fixed $\mathrm{P}_{\text {plat }}$ of $45 \mathrm{~cm}$ $\mathrm{H}_{2} \mathrm{O}$ as a surrogate measure of total lung capacity.

Third, over the years, recruitment maneuver studies have utilized different measurement techniques that have influenced both the results and their interpretation. ${ }^{32}$ Recruitment inferred from chest mechanics (eg, change in end-expiratory lung volume measured during construction of pressure-volume curves or after step changes in PEEP) reflects increased aeration of partially and fully inflated alveoli, as well as recruitment of previously collapsed or noncommunicating alveoli. In this review, we have focused on CT-based studies. Although ambiguities exist with this technique, it nonetheless provides a high degree of differentiation between non-, poorly and well-inflated alveoli (see below). As would be anticipated, recruitment inferred from chest mechanics analysis estimate much greater recruitment than those based on CT analysis. ${ }^{32}$

Taken together, these potential confounding variables (ie. relatively small numbers of study subjects, variations in both technique and primary endpoints) limit the generalizability of recruitment maneuver study results to individual patients, let alone navigating the contentious discourse regarding their interpretation.

\section{Sponge Theory and Superimposed Hydrostatic Pressures}

Setting aside common clinically induced causes (eg, circuit disconnection, endotracheal suctioning), lung derecruitment in ARDS is thought to be caused largely by super-imposed hydrostatic pressure of overlying edematous lung tissue and mediastinal structures, as well as increased weight of the chest wall (eg, thoracic anasarca, ascites). ${ }^{94}$ This is based upon the sponge theory posited to explain rapid redistribution of lung densities on $\mathrm{CT}$ scans from dorsal to ventral regions during placement in prone position. ${ }^{76}$ Two facts support the notion that this represents a shift in gravitational forces applied to the lungs. First, overall lung density was unchanged, suggesting lung tissue mass (ie, edema, blood, cellular content or debris) had remained stable. ${ }^{99}$ Second, although pulmonary edema clearance in ARDS is severely impaired $(6 \% / \mathrm{h}),{ }^{100}$ edema fluid is removed through the lymphatic system and does not freely redistribute through lung tissue. ${ }^{99}$

\section{PEEP and De-Recruitment}

A recurring and relatively uniform finding in many of the early recruitment maneuver studies was that, when ventilation was resumed at the previous PEEP level, oxygenation improvements dissipated rapidly over time despite relatively high baseline PEEP $(\sim 12-15 \mathrm{~cm}$ $\left.\mathrm{H}_{2} \mathrm{O}\right){ }^{22,23,27,101,102}$ In contrast, oxygenation improvements could be sustained following recruitment maneuver when higher post-recruitment maneuver PEEP levels were maintained (eg, $\sim 6-7 \mathrm{~cm} \mathrm{H}_{2} \mathrm{O}$ above baseline). ${ }^{21}$ Acute lung injury models also reported that oxygenation after a recruitment maneuver was PEEP-dependent, with the highest sustained improvement occurring at PEEP of $16 \mathrm{~cm} \mathrm{H}_{2} \mathrm{O}$ (vs 12 or $8 \mathrm{~cm} \mathrm{H}_{2} \mathrm{O}$ ). ${ }^{77}$ That the sustained improvement was independent of recruitment maneuver methodology suggests recruitment and de-recruitment occur through different mechanisms.

When pleural pressure exceeds alveolar pressure at endexpiration, de-recruitment occurs over time irrespective of previous volume history. ${ }^{73}$ In ARDS, de-recruitment is a continuous process that becomes prominent at PEEP $<15$ $\mathrm{cm} \mathrm{H}_{2} \mathrm{O}^{85}$ De-recruitment appears to cease in the upper and hilar lung zones at PEEP of $10 \mathrm{~cm} \mathrm{H}_{2} \mathrm{O}$, whereas it continues in dorsal regions, reaching a maximum collapse rate at $5 \mathrm{~cm} \mathrm{H}_{2} \mathrm{O} .{ }^{85}$ De-recruitment modeling suggests the speed of collapse also increases as PEEP decreases. ${ }^{59}$ Similarly, a decremental PEEP study noted that pleural pressure exceeded alveolar pressure once PEEP decreased below $9 \pm 5 \mathrm{~cm} \mathrm{H}_{2} \mathrm{O}$, whereas in some subjects de-recruitment occurred at $\mathrm{PEEP}<20 \mathrm{~cm} \mathrm{H}_{2} \mathrm{O}^{73}$

These findings suggest 3 potential PEEP targets that might reduce de-recruitment during the acute phase of ARDS: (1) minimum PEEP of 10-12 $\mathrm{cm} \mathrm{H}_{2} \mathrm{O}$, (2) a general target of $16 \mathrm{~cm} \mathrm{H}_{2} \mathrm{O}$, and (3) $\geq 20 \mathrm{~cm} \mathrm{H}_{2} \mathrm{O}$ in very severe cases, particularly those with reduced chest wall compliance. This is similar to the better PEEP strategy proposed by Gattinoni and colleagues. ${ }^{103}$

\section{Superimposed Pressure, De-Recruitment, and ARDS Severity}

The largest and perhaps most comprehensive CT study reported the maximum range of ventral-dorsal superimposed hydrostatic pressure was $6-18 \mathrm{~cm} \mathrm{H}_{2} \mathrm{O} .{ }^{94}$ Interestingly, the mean hydrostatic pressure was similar between Berlin classifications of mild, moderate, and severe ARDS $\left(12 \pm 3,12 \pm 2,13 \pm 1 \mathrm{~cm} \mathrm{H}_{2} \mathrm{O}\right.$, respectively, $P=.053)$. Factoring in PEEP required to counter both superimposed hydrostatic pressure and chest wall 


\section{ReCruitment AND De-Recruitment in ARDS Management}

elastance yielded PEEP estimates of $16 \pm 8,16 \pm 5$, and $18 \pm 5 \mathrm{~cm} \mathrm{H}_{2} \mathrm{O}$, respectively $(P=.48)$.

A particularly interesting finding was that PEEP requirements did not differ between those characterized as having low or high recruitment potential and based on the observation that maximum superimposed hydrostatic pressure between the 2 groups differed by only $1-2 \mathrm{~cm} \mathrm{H}_{2} \mathrm{O}$. Thus, neither superimposed hydrostatic pressure nor chest wall elastance correlated appreciably with recruitment potential.

This implies that superimposed hydrostatic pressure enters the calculus of setting PEEP to preserve lung stability following recruitment rather than causing recruitment. These observations led the authors to dissuade clinicians from reflexively treating low recruitability (ie, lobar ARDS) with PEEP levels of $\sim 15 \mathrm{~cm} \mathrm{H}_{2} \mathrm{O}$ simply to prevent shear injury in "a few grams of lung tissue," given the greater risk of hemodynamic compromise and regional overdistention in middle and ventral lung zones. ${ }^{94}$

\section{Elevated Intra-Abdominal Pressure in ARDS}

The ventral-dorsal pleural pressure gradient in the supine position determines resting alveolar size and largely reflects gravitational forces imposed by the abdomen, which is a more dense, fluid-like compartment with a volume twice that of an air-filled thorax. ${ }^{104,105}$ Normal intra-abdominal pressure (IAP) is $\sim 5-7 \mathrm{~mm} \mathrm{Hg}\left(7-10 \mathrm{~cm} \mathrm{H}_{2} \mathrm{O}\right)$, whereas intra-abdominal hypertension is defined as IAP $>12 \mathrm{~mm}$ $\mathrm{Hg}\left(16 \mathrm{~cm} \mathrm{H}_{2} \mathrm{O}\right)$ with $20-60 \%$ pressure transmission to the thorax. ${ }^{106}$ Therefore, severe hypoxemia coinciding with intra-abdominal hypertension is a compelling indication for OLV.

\section{Thoracoabdominal Mechanics, De-Recruitment, and Intra-Abdominal Hypertension}

Elevated IAP displaces the diaphragm cephalad into the thorax and stiffens the abdominal portion of the chest wall, such that pleural pressure becomes more positive. This is particularly acute in the dorsal-caudal regions in the supine position, causing reduced lung and chest wall compliance, increased tissue and airways resistance, and compressive atelectasis. ${ }^{107-109}$ Under these conditions, alveolar de-recruitment from tissue compression (vs alveolar consolidation) is more likely the primary cause of refractory hypoxemia, hence a recruitment maneuver is more likely to be effective.

Abdominal compartment syndrome (IAP $>25 \mathrm{~mm} \mathrm{Hg}$; $\left.>34 \mathrm{~cm} \mathrm{H}_{2} \mathrm{O}\right)^{110}$ is associated with substantial nonaerated and poorly aerated lung tissue $(23 \%$ and $18 \%$, respectively). ${ }^{11}$ At these extraordinary pressures, respiratory system inertance, normally considered negligible, may become significant and therefore would increase TOP. ${ }^{112}$ Inertance refers to the acceleration of gas molecules as well as displacement of resting lung and chest wall tissues, including the abdominal contents. ${ }^{109}$

During quiet breathing with normal body habitus, inertance accounts for $<5 \%$ of driving pressure. ${ }^{113}$ In morbid obesity, inertance is $\sim 4$-fold higher, and up to $68 \%$ can be accounted for by chest wall tissue. ${ }^{109}$ Although its relevance to ARDS is unknown, it is notable that, in morbidly obese subjects, the driving pressure required to overcome inertance alone during maximal ventilation maneuvers reaches $40 \mathrm{~cm} \mathrm{H}_{2} \mathrm{O} .{ }^{109}$ In a case of ARDS and abdominal compartment syndrome, a similar driving pressure $\left(\mathrm{P}_{\text {plat }} 80\right.$ $\mathrm{cm} \mathrm{H}_{2} \mathrm{O}$ and PEEP 45-50 $\mathrm{cm} \mathrm{H}_{2} \mathrm{O}$ ) was required to increase $\mathrm{P}_{\mathrm{aO}}$ from 23 to $350 \mathrm{~mm} \mathrm{Hg}$ when surgical decompression could not be attempted. ${ }^{70}$

\section{Intra-Abdominal Hypertension and ARDS}

Intra-abdominal hypertension is common in severe ARDS $^{108}$ and is particularly prevalent in extrapulmonary cases. ${ }^{43}$ It occurs in pulmonary ARDS complicated by morbid obesity (ie, mass loading), where IAP is $\sim 12-19 \mathrm{~cm}$ $\mathrm{H}_{2} \mathrm{O},{ }^{114}$ as well as other conditions such as ascites from abdominal sepsis, pancreatitis, or hepatic failure. ${ }^{115,116}$ In acute lung injury models, IAP of $20 \mathrm{~cm} \mathrm{H}_{2} \mathrm{O}$ greatly exacerbated pulmonary edema formation and increased intrapulmonary shunting. ${ }^{117,118}$ Mean IAP of $\sim 22 \mathrm{~cm} \mathrm{H}_{2} \mathrm{O}^{43,116,119}$ and endexpiratory esophageal pressures of $\sim 20 \mathrm{~cm} \mathrm{H}_{2} \mathrm{O}$ have been reported in cases of severe ARDS. ${ }^{120}$

IAP is particularly relevant in treating refractory hypoxemia. A preclinical study reported that, at IAP of $24-35 \mathrm{~cm}$ $\mathrm{H}_{2} \mathrm{O}$, high PEEP (ie, $15 \mathrm{~cm} \mathrm{H}_{2} \mathrm{O}$ ) was equally ineffective as low to moderate PEEP (ie, 5-12 $\mathrm{cm} \mathrm{H}_{2} \mathrm{O}$ ) in improving FRC and $\mathrm{P}_{\mathrm{aO}_{2}} / \mathrm{F}_{\mathrm{IO}_{2}} \cdot{ }^{121}$ This led to a follow-up study of IAP-matching PEEP in acute lung injury with intra-abdominal hypertension (ie, 16-25 cm H $\mathrm{H}_{2} \mathrm{O}$ ). Higher levels of $\mathrm{P}_{\text {plat }}$ and PEEP used in the pressure control ventilation recruitment maneuver strategies described above were needed to improve FRC and oxygenation (Fig. 4). ${ }^{117}$

Adding half of the measured IAP to the recruitment maneuver pressure targets has been suggested ${ }^{106}$ For example, a recruitment maneuver of $45 \mathrm{~cm} \mathrm{H}_{2} \mathrm{O}^{92}$ applied to IAP representing conditions of intra-abdominal hypertension (16 $\left.\mathrm{cm} \mathrm{H}_{2} \mathrm{O}\right)$, average IAP in reported in ARDS $\left(22 \mathrm{~cm} \mathrm{H}_{2} \mathrm{O}\right)$ or severe abdominal compartment syndrome $(\geq 50 \mathrm{~cm}$ $\left.\mathrm{H}_{2} \mathrm{O}\right)^{110,122}$ would require adjusting $\mathrm{P}_{\text {plat }}$ upward to 53,56 , and $70 \mathrm{~cm} \mathrm{H}_{2} \mathrm{O}$, respectively.

Attempting a recruitment maneuver in a patient with intra-abdominal hypertension requires assessing overall risk/benefit ratio. Elevated pleural and intra-abdominal pressures impede hemodynamic function and lymphatic drainage and therefore carries the risk of worsening both pulmonary edema and intra-abdominal hypertension as well as risking hemodynamic collapse. ${ }^{123}$ In the context of abdominal compartment syndrome, it should probably be 


\section{ReCruitment And De-Recruitment in ARDS Management}

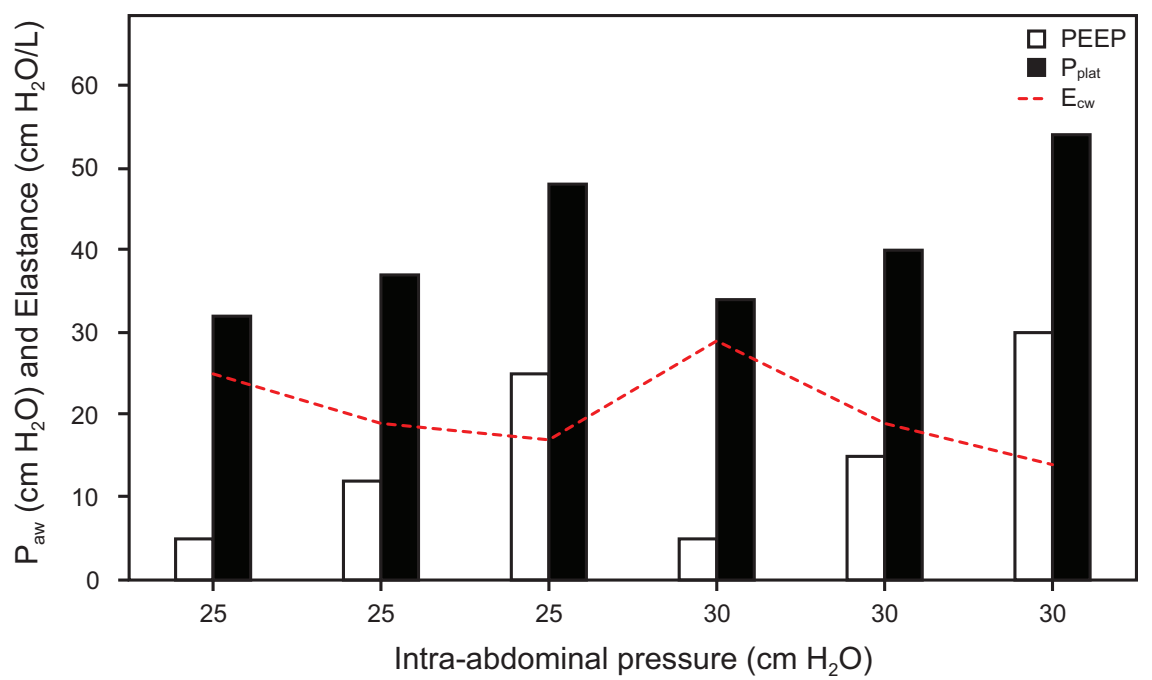

Fig. 4. Relationship between PEEP, plateau pressure $\left(P_{\text {plat }}\right)$ and chest wall elastance $\left(E_{c w}\right)$ at increasing levels of intra-abdominal pressure in an animal model of acute lung injury. Data from Reference 118.

considered only when surgical decompression carries an even greater risk.

\section{Impact of PEEP on Volume Distribution in ARDS}

Finally, regardless of $\mathrm{P}_{\text {plat }}$ or PEEP, gas distribution in ARDS steadily decreases down the ventral-dorsal axis with an upper-to-lower lung volume distribution ratio of 2.2:1 at ambient end-expiratory pressure. At PEEP of $20 \mathrm{~cm} \mathrm{H}_{2} \mathrm{O}$ ventral-dorsal gas distribution was essentially equivalent $(1.1: 1){ }^{81}$ For the dorsal regions (ie, those having the greatest impact on gas exchange) this volume redistribution translated into increased end-expiratory lung volumes from $\sim 10 \%$ to $25 \%$ and increased end-inspiratory lung volumes from $15 \%$ to $35 \%$. These findings were supported by an electrical impedance tomography study of OLV wherein ventral/dorsal tidal volume ratio decreased from $2.01 \pm$ 0.36 to $1.19 \pm 0.10(P<.01) .{ }^{124}$

\section{Ambiguous and Perplexing Nature of Recruitment Phenomena}

In ARDS, improvements in radiologic imaging, gas exchange, and lung mechanics during and following recruitment maneuver represent complex, histopathologic responses of injured lungs and chest wall forces to applied pressure, and thus are open to interpretation. This section describes some of the vagaries that limit our interpretation of the efficacy of recruitment maneuver.

\section{Radiologic Factors}

CT scans are the accepted standard for evaluating topographic distribution of aerated and nonaerated lung tissue
Table 2. Interpretation of Lung Function Based on Computed Tomography Imaging

\begin{tabular}{ll}
\hline $\begin{array}{l}\text { Radiologic Quantification, } \\
\text { Hounsfield Units }\end{array}$ & \multicolumn{1}{c}{ Used to Signify } \\
\hline$+1,000$ & Bone \\
0 & Tissue (defined as $50 \%$ tissue, $50 \%$ air) \\
$-1,000$ & Air \\
$-1,000$ to -900 & Hyperinflated tissue \\
-900 to -500 & Normally aerated tissue \\
-500 to -100 & Poorly aerated tissue \\
-100 to +100 & Non-aerated tissue \\
\hline
\end{tabular}

in ARDS, inferred by the lungs ability to attenuate $\mathrm{x}$ rays. ${ }^{125}$ The radiologic definition of consolidation is markedly increased lung attenuation obscuring pulmonary vessels caused by atelectasis or alveolar filling, whereas in pathology the term specifically refers to the latter. ${ }^{126}$ Attenuation is measured by the Hounsfield linear density scale that assigns a numeric value (Hounsfield units [HU]) differentiating between bone $(+1,000 \mathrm{HU})$, water $(0 \mathrm{HU})$ and air $(-1,000 \mathrm{HU}) .{ }^{127}$ Values between these 3 points are used to convey various states of pulmonary tissue, with values between $-100 \mathrm{HU}$ and $+100 \mathrm{HU}$ considered to represent collapsed tissue (Table 2)..$^{12,81,94,128}$

From these interpretations, pulmonary gas-tissue ratios are calculated and used to infer the response to recruitment maneuver and PEEP. Yet, the designation of lung "tissue" also includes extravascular fluid and blood. ${ }^{127}$ Thus, CT imaging represents "the quantity of air being introduced into a diseased lung," hence the statement, "one pixel is not an alveolus." "15 Lung CT imaging interpretation relies upon an unprovable assumption of homogenous alveolar filling in condensed lung tissue, whereas in reality it likely 


\section{ReCruitment AND De-Recruitment in ARDS Management}

includes already aerated alveoli. ${ }^{56,115}$ In addition, estimating the reduction in nonaerated tissue is dependent upon the number of CT sections sampled (compared to whole lung scans). For example, a single juxta-diaphragmatic section may result in either over- or underestimation of recruitment, whereas adding samples of apical and hilar regions tends to overestimate recruitment. ${ }^{129}$

In spite of the strong association found between radiologic assessment of alveolar recruitment and oxygenation, ${ }^{40,130}$ a complex interaction of other factors contributes to improved oxygenation (eg, increased ventilation-perfusion matching, ${ }^{131}$ decreased cardiac output with redistribution of pulmonary perfusion, ${ }^{132}$ reduced edema formation, ${ }^{133}$ and its redistribution to the perivascular spaces ${ }^{56,134}$ ). Skeptics claim radiologic evidence supporting lung recruitment are "inferences about alveolar micromechanics from measurements made on a scale several orders of magnitude greater than that of the structures of interest." ${ }^{\prime 135}$ The volume element of a CT image (ie, the voxel) is $\sim 2-2.6 \mathrm{~mm}^{3}, 32,127$ whereas a single alveolus is $\sim 0.12 \mathrm{~mm}^{3} .{ }^{136}$ Thus, a single voxel may represent a tissue section consisting of $\sim 15$ discrete alveoli.

The importance of this limitation becomes apparent in lung microimaging of gas dynamics within alveolar clusters. Animal models of acute lung injury observed pronounced pendelluft motion between adjacent alveoli (some slowly inflating during expiration, some deflating during inspiration), as well as paradoxically simultaneous recruitment and de-recruitment, while still others either synchronously inflate and deflate or appear stunned (ie, remaining motionless at a constant volume). ${ }^{137,138}$ This localized interalveolar asynchrony and instability results from mechanical interdependency between neighboring alveoli and increases with the severity of injury. ${ }^{138}$ Although CT imaging studies provide invaluable information on the nature of recruitment and de-recruitment, they are clinically impractical for routine use; in addition, there remains assumptive ambiguity and therefore a risk of over-interpretation.

\section{Rheologic Factors}

During expiration, distal airway de-recruitment occurs as increasing surface tension causes liquid bridges to reform, drawing airway and alveolar walls together. ${ }^{56,139}$ An in vivo study of acute lung injury confirmed the presence of liquid menisci forming dense bridges across small peripheral airways. ${ }^{138}$ Therefore, the perception of alveolar recruitment in acutely injured lungs may be explained as the breaking of foam bridges and displacement of pulmonary edema fluid, resulting in increased alveolar ventilation. ${ }^{56,135,140}$ Thus, other factors determine the force required to re-open the lungs: surface-tension forces (accounting for 50-60\% of lung elastance), the presence of biologically active surfactant (in both alveoli and distal airways), viscosity and thickness of airway edema, and overcoming strain energy in collapsed small airways (see below). ${ }^{48-50,56,139,141}$

Even sponge model proponents acknowledge that compression atelectasis likely represents a mixture of alveolar and small airway collapse. ${ }^{81}$ What remains undisputed is that specific and reproducible ranges of airway pressures transmitted to the lung parenchyma are required to improve regional aeration and gas exchange in ARDS, and that the recruitment of collapsed or obstructed airways and alveoli invariably involves epithelial cell deformation and therefore likely causes shear injury ${ }^{139,140}$ and exacerbates baseline airway epithelial injury associated with ARDS. ${ }^{45}$ Greater injury is thought to occur with reopening collapsed versus obstructed airways. ${ }^{140}$

\section{Histopathologic Factors}

Ambiguity surrounding the effectiveness and appropriateness of recruitment maneuvers partly depends upon whether atelectasis (ie, degassed alveoli), intra-alveolar edema (ie, flooded alveolar units and peripheral airways), or interstitial edema is the predominant lesion causing refractory hypoxemia, as well as the intensity of edema. ${ }^{98}$ Historically the most prominent autopsy findings in early ARDS included some combination of interstitial and alveolar edema or hemorrhage and hyaline membranes, ${ }^{142-152}$ along with a substantial subset reporting atelectasis. ${ }^{144,145,147,149,153}$ In what eventually would be called ARDS, the term congestive atelectasis was used to describe "diffuse non-obstructive collapse of pulmonary alveoli and intense interstitial edema and pulmonary capillary congestion," ${ }^{147}$ leading to excessive surface tension forces causing collapse. ${ }^{148}$ More recently, this has been redefined as inflammatory (ie, congestive) atelectasis versus compression atelectasis. ${ }^{154}$

These characteristics defined diffuse alveolar damage, the histopathologic hallmark of ARDS. ${ }^{142}$ During the first week of ARDS confirmed with diffuse alveolar damage, intra-alveolar edema tends to be highest ( $90 \%$ of cases) but remains prevalent during subsequent weeks $(74 \%$ of cases). ${ }^{155}$ Only $\sim 50 \%$ of ARDS cases now present with diffuse alveolar damage, ${ }^{156}$ its decrease coinciding with the emergence of LPV. ${ }^{157}$ ARDS without diffuse alveolar damage has been associated primarily associated with pneumonia. This is characterized less by intense interstitial edema and alveolar neutrophil infiltration localized in the terminal bronchioles. ${ }^{156,158}$

A study that matched PEEP responsiveness to lung biopsy and autopsy samples reported that subjects exhibiting minimal oxygenation response had complete alveolar filling with purulent or hemorrhagic material. Those exhibiting the greatest oxygenation response had less intense alveolar edema and were distinguished by hyaline membrane formation, interstitial edema, and atelectasis. ${ }^{159}$ 


\section{ReCruitment AND De-Recruitment in ARDS Management}

\section{Direct Versus Indirect Injury and Injury Severity}

Both direct and indirect forms of ARDS include alveolar collapse, ${ }^{42}$ yet direct (ie, alveolar epithelial) injury has been characterized more by intense collapse and alveolar edema but minimal interstitial edema, whereas indirect (ie, capillary endothelial) injury is associated with more intense interstitial edema than alveolar edema. ${ }^{160}$ Similar findings were reported in other studies. ${ }^{126}$ Moreover, direct injury has been associated with higher pulmonary microvascular permeability that, over a period of days, coincides with higher levels of extravascular lung water. ${ }^{161}$ Some evidence suggests that recruitment maneuver (at least when using the sustained inflation technique) might be ineffective in the presence of high extravascular lung water $(\sim 16 \mathrm{~mL} / \mathrm{kg}){ }^{98}$

Inconsistencies between histologic findings in ARDS likely have many sources due to the limited number of samples, the heterogeneous nature of ARDS and associated lesions, and its timing relative to syndrome onset. Irrespective of these, such inconsistencies suggest that simplistic conceptual models guiding recruitment maneuver have limited utility because the varied histopathologic changes in ARDS coexist across a spectrum and that lesions evolve over time. ${ }^{159}$ Moreover, direct injury from pneumonia disrupting alveolar membrane integrity (ie, loss of bacterial compartmentalization) can induce indirect, secondary injury to noninfected lung regions through systemic cytokine release. ${ }^{162}$ In fact, a substantial number of subjects with ARDS with either aspiration or pneumonia as primary etiology also have sepsis as a secondary source of lung injury (20\% and $40 \%$, respectively). ${ }^{163}$

Furthermore, secondary analysis of several recruitment maneuver CT studies concluded that recruitment is likely determined more by the severity of injury and corresponding edema formation than injury mechanism per se. ${ }^{93}$ As lung injury severity increases, so too does the degree of pulmonary capillary permeability and the magnitude of extravascular lung water. ${ }^{164}$ In general, regardless of injury mechanisms, greater recruitment potential is present in ARDS characterized by diffuse versus predominant dorsal opacities. ${ }^{101,165-167}$ Unfortunately, this is not a distinction that can be made by clinicians when chest radiographs are the only practical tool available when contemplating whether to pursue treating refractory hypoxemia with recruitment maneuver.

In a secondary analysis of recruitment maneuver studies evaluated with CT, estimates of recruitability were actually higher in direct injury. ${ }^{93}$ Several factors were cited that provide important insights into the interpretation of recruitment maneuver studies. First, the timing of recruitment maneuver relative to ARDS onset influences recruitability. Over time, edema fluid is slowly reabsorbed while concurrently fibrotic and tissue repair mechanisms evolve.
Second, the duration and fidelity to LPV prior to initiating a recruitment maneuver will influence recruitment potential regardless of injury mechanism. Third, the higher correlation between direct injury and ARDS severity may reflect the degree of bacterial diffusion throughout the lung parenchyma. ${ }^{93}$ This in turn suggests relatively greater consolidation in direct injury (with a corresponding brisk reactive edema formation) possibly producing greater edema than that caused by distant organ injury. However, the investigators stressed that extrapulmonary injury or infection can cause equivalent severity. Thus, when only a small number of subjects are studied (ie, selection bias), the results may suggest equivalence, relatively greater, or relatively lesser lung recruitability between direct versus indirect injury.

\section{$P_{\text {plat }}$ and PEEP During LPV}

Oxygenation goals in LPV tend to align with the leastPEEP philosophy, whereby the objective is using the lowest PEEP that provides a reasonable $\mathrm{P}_{\mathrm{aO}}(\geq 70 \mathrm{~mm} \mathrm{Hg})$ at a relatively non-toxic $\mathrm{F}_{\mathrm{IO}_{2}}(\leq 0.60) .{ }^{168}$ Only when clearly toxic levels of $\mathrm{F}_{\mathrm{IO}_{2}}(\geq 0.70)^{169}$ are necessary are higher PEEP levels generally used $\left(>10 \mathrm{~cm} \mathrm{H}_{2} \mathrm{O}\right){ }^{18}$

In traditional LPV, tidal volume is titrated to achieve a $\mathrm{P}_{\text {plat }} \leq 30 \mathrm{~cm} \mathrm{H}_{2} \mathrm{O} .{ }^{18}$ Slightly more stringent LPV variants have focused on minimizing the risk of right-ventricular dysfunction and cor pulmonale $\left(\mathrm{P}_{\text {plat }} \leq 26 \mathrm{~cm} \mathrm{H}_{2} \mathrm{O}\right)^{170,171}$ or the risk of tidal overdistention $\left(\mathrm{P}_{\text {plat }} \leq 27 \mathrm{~cm} \mathrm{H}_{2} \mathrm{O}\right) .{ }^{172}$ Given the heterogeneity of ARDS and large variability in oxygenation dysfunction, it is important to have some perspective as to how often traditional LPV goals fall short of securing adequate oxygenation at relatively non-toxic levels of $\mathrm{F}_{\mathrm{IO}_{2}}$.

The mechanistic studies reviewed above suggest that a $\mathrm{P}_{\text {plat }}$ of $30 \mathrm{~cm} \mathrm{H}_{2} \mathrm{O}$ effects almost complete recruitment in the mid-lung (CT regions 4-7) and simultaneously the largest incremental changes in the dorsal lung (regions 8-10). In addition, de-recruitment becomes apparent at PEEP $<15$ $\mathrm{cm} \mathrm{H}_{2} \mathrm{O}$ and is particularly prominent in the dorsal regions only at PEEP $<10 \mathrm{~cm} \mathrm{H}_{2} \mathrm{O}^{85,92}$ Therefore, assuming normal body habitus, a PEEP of $10-15 \mathrm{~cm} \mathrm{H}_{2} \mathrm{O}$ and $\mathrm{P}_{\text {plat }}$ of 26-30 $\mathrm{cm} \mathrm{H}_{2} \mathrm{O}$ appears sufficient to ensure adequate oxygenation at relatively non-toxic levels of $\mathrm{F}_{\mathrm{IO}_{2}}$ in the majority of ARDS cases.

Data from 3 major LPV trials ${ }^{173-175}$ involving $>2,300$ subjects with early ARDS compared 2 PEEP strategies support this interpretation. These studies found that: (1) moderate PEEP of 8-10 $\mathrm{cm} \mathrm{H}_{2} \mathrm{O}$ produced a mean $\mathrm{P}_{\text {plat }}$ of 21-25 $\mathrm{cm}_{2} \mathrm{O}$ and was generally sufficient to achieve an adequate to normal $\mathrm{P}_{\mathrm{aO}}$ on relatively non-toxic levels of $\mathrm{F}_{\mathrm{IO}_{2}}$; (2) higher PEEP (ie, $\sim 15 \mathrm{~cm} \mathrm{H}_{2} \mathrm{O}$ ) with mean $\mathrm{P}_{\text {plat }}<30 \mathrm{~cm}$ $\mathrm{H}_{2} \mathrm{O}$ further improved $\mathrm{P}_{\mathrm{aO}_{2}}$ at a decidedly less toxic levels of $\mathrm{F}_{\mathrm{IO}_{2}}$; and (3) by the third study day, oxygenation 


\section{ReCruitment AND De-Recruitment in ARDS Management}

Table 3. Oxygenation and $\mathrm{P}_{\text {plat }}$ Differences in 3 Trials of Lower vs Higher PEEP During Lung-Protective Ventilation

\begin{tabular}{|c|c|c|c|c|}
\hline \multirow{2}{*}{ Study } & \multicolumn{2}{|c|}{ Day 1} & \multicolumn{2}{|c|}{ Day 3} \\
\hline & Lower PEEP & Higher PEEP & Lower PEEP & Higher PEEP \\
\hline \multicolumn{5}{|l|}{ ALVEOLI $^{173}$} \\
\hline PEEP, $\mathrm{cm} \mathrm{H}_{2} \mathrm{O}^{*}$ & $9 \pm 4$ & $15 \pm 4$ & $9 \pm 4$ & $13 \pm 5$ \\
\hline $\mathrm{P}_{\text {plat }}, \mathrm{cm} \mathrm{H} \mathrm{H}_{2} \mathrm{O}$ & $24 \pm 7$ & $27 \pm 6$ & $24 \pm 6$ & $26 \pm 7$ \\
\hline $\mathrm{F}_{\mathrm{IO}_{2}}$ & $0.54 \pm 0.18$ & $0.44 \pm 0.17$ & $0.52 \pm 0.18$ & $0.40 \pm 0.14$ \\
\hline $\mathrm{P}_{\mathrm{aO}_{2}}, \mathrm{~mm} \mathrm{Hg}$ & $78 \pm 22$ & $85 \pm 28$ & $77 \pm 22$ & $74 \pm 20$ \\
\hline $\mathrm{P}_{\mathrm{aO}_{2}} / \mathrm{F}_{\mathrm{IO}_{2}}$ & $168 \pm 66$ & $220 \pm 89$ & $169 \pm 69$ & $206 \pm 76$ \\
\hline \multicolumn{5}{|l|}{ EXPRESS ${ }^{174}$} \\
\hline PEEP, $\mathrm{cm} \mathrm{H}_{2} \mathrm{O} \dagger$ & $8 \pm 2$ & $16 \pm 3$ & $8 \pm 2$ & $15 \pm 4$ \\
\hline $\mathrm{P}_{\text {plat }}, \mathrm{cm} \mathrm{H}_{2} \mathrm{O}$ & $21 \pm 5$ & $28 \pm 2$ & $21 \pm 5$ & $27 \pm 4$ \\
\hline $\mathrm{F}_{\mathrm{IO}_{2}}$ & $0.66 \pm 0.21$ & $0.55 \pm 0.19$ & $0.58 \pm 0.20$ & $0.46 \pm 0.17$ \\
\hline $\mathrm{P}_{\mathrm{aO}_{2}}, \mathrm{~mm} \mathrm{Hg}$ & $89 \pm 34$ & $108 \pm 43$ & $91 \pm 37$ & $102 \pm 38$ \\
\hline $\mathrm{P}_{\mathrm{aO}_{2}} / \mathrm{F}_{\mathrm{IO}_{2}}$ & $150 \pm 69$ & $218 \pm 97$ & $175 \pm 81$ & $245 \pm 98$ \\
\hline \multicolumn{5}{|l|}{ LOVS $^{175}$} \\
\hline PEEP, $\mathrm{cm} \mathrm{H}_{2} \mathrm{O} \ddagger$ & $10 \pm 3$ & $16 \pm 4$ & $9 \pm 3$ & $12 \pm 4$ \\
\hline $\mathrm{P}_{\text {plat }}, \mathrm{cm} \mathrm{H} \mathrm{H}_{2} \mathrm{O}$ & $25 \pm 5$ & $30 \pm 6$ & $25 \pm 6$ & $29 \pm 6$ \\
\hline $\mathrm{F}_{\mathrm{IO}_{2}}$ & $0.58 \pm 0.17$ & $0.50 \pm 0.16$ & $0.41 \pm 0.12$ & $0.52 \pm 0.16$ \\
\hline $\mathrm{P}_{\mathrm{aO}_{2}}, \mathrm{~mm} \mathrm{Hg}$ & $80 \pm 26$ & $88 \pm 32$ & $76 \pm 16$ & $75 \pm 15$ \\
\hline $\mathrm{P}_{\mathrm{aO}_{2}} / \mathrm{F}_{\mathrm{IO}_{2}}$ & $149 \pm 61$ & $187 \pm 69$ & $164 \pm 64$ & $197 \pm 61$ \\
\hline \multicolumn{5}{|c|}{$\begin{array}{l}\text { * After the first interim analysis, the Higher PEEP protocol was amended to require a minimum PEEP of } 14 \mathrm{~cm} \mathrm{H}_{2} \mathrm{O} \text { for } 48 \mathrm{~h} \text { due to a lack of differer } \\
\text { addition, the first } 80 \text { subjects in the Higher PEEP arm underwent } 1-2 \text { sustained inflation recruitment maneuvers with CPAP at } 35-40 \mathrm{~cm} \mathrm{H}_{2} \mathrm{O} \text { for } 30 \mathrm{~s} \\
\text { continued for lack of sustained oxygenation response. } \\
\text { TTotal PEEP rather than set PEEP reported. } \mathrm{P}_{\text {plat }} \text { was limited to } 30 \mathrm{~cm} \mathrm{H}_{2} \mathrm{O} \text { in the Higher PEEP arm. } \\
\text { "The Higher PEEP arm included a } \mathrm{P}_{\text {plat }} \text { limit of } 40 \mathrm{~cm} \mathrm{H}_{2} \mathrm{O} \text { and use of a sustained inflation recruitment maneuver with CPAP at } 40 \mathrm{~cm} \mathrm{H}_{2} \mathrm{O} \text { for } 40 \mathrm{~s} \text {. } \\
\mathrm{P}_{\text {plat }}=\text { end-inspiratory plateau pressure }\end{array}$} \\
\hline
\end{tabular}

had either stabilized or improved regardless of PEEP strategy. These findings strongly suggest that a recruitment maneuver is unnecessary to manage the majority of ARDS cases and needlessly increases the risk/benefit ratio (Table 3 ).

Mean data, however, cannot elucidate whether $\mathrm{P}_{\text {plat }}$ generated by PEEP levels used during traditional LPV would: (1) likely reach suggested nodal points of TOP associated with full recruitment of dorsal regions; (2) estimate the percentage of subjects requiring toxic levels of $\mathrm{F}_{\mathrm{IO}_{2}}$; and (3) gauge how many subjects would be reasonable candidates for recruitment maneuver therapy. We examined these issues by querying databases used in our prior studies. ${ }^{163,176}$ Our results are discussed in detail in online supplementary materials (see the supplementary materials at http://www. rcjournal.com); however, the 2 main findings are: (1) tidal volume titration effectively limited $\mathrm{P}_{\text {plat }}$ to desired levels despite high PEEP levels; and (2) this limited the likelihood for substantial dorsal lung recruitment in severe refractory hypoxemia, as even at PEEP $>16 \mathrm{~cm} \mathrm{H}_{2} \mathrm{O}$ only $5 \%$ of subjects reached a sufficiently high recruitment threshold of 45 $\mathrm{cm} \mathrm{H}_{2} \mathrm{O}$. Thus, there is a subset of severe ARDS cases in which traditional LPV is insufficient and a recruitment maneuver would appear to be a reasonable option to reverse refractory hypoxemia.

\section{Optimizing Oxygenation and Minimizing Risk of Atelectrauma}

FRC represents the alveolar volume and is the primary determinant of $\mathrm{P}_{\mathrm{aO}_{2}} \cdot{ }^{177}$ Therefore, increased $\mathrm{P}_{\mathrm{aO}}$ in response to increased PEEP or recruitment maneuver is a bedside convenience to infer changes in FRC and, by extension, shear injury risk. Unfortunately, the logic linking these 3 phenomena is precarious.

Depending upon $\mathrm{P}_{\text {plat }}$, a substantial portion of early FRC increase (ie, the fast pulmonary compartment) represents expansion of normally inflated or underinflated alveoli and not recruitment. ${ }^{4}$ In addition, arbitrary $\mathrm{P}_{\mathrm{aO}_{2}} / \mathrm{F}_{\mathrm{IO}_{2}}$ thresholds used to signify full recruitment (ie, $250-330 \mathrm{~mm} \mathrm{Hg})^{40,72}$ are literally false. Full recruitment implies normal pulmonary oxygen diffusion function (eg, $\mathrm{P}_{\mathrm{aO}_{2}} / \mathrm{F}_{\mathrm{IO}_{2}} \geq 450 \mathrm{~mm}$ $\mathrm{Hg}$ ). This does not occur in ARDS because of varying degrees of tissue consolidation and slow resolution of pulmonary edema. Thus, the $\mathrm{P}_{\mathrm{aO}_{2}} / \mathrm{F}_{\mathrm{IO}_{2}}$ thresholds of 250-330 $\mathrm{mm} \mathrm{Hg}$ used to evaluate recruitment maneuver effectiveness suggest a tacit acknowledgment that the term full recruitment is meant figuratively.

Beyond these vagaries lies the crux of the debate: Does OLV materially reduce the risk of repetitive shear injury compared to traditional LPV? This is unlikely for the 


\section{ReCruitment AND De-Recruitment in ARDS Management}

majority of ARDS cases. First, a $\mathrm{P}_{\text {plat }}$ of $\geq 40 \mathrm{~cm} \mathrm{H}_{2} \mathrm{O}$ is needed to reopen distal airways and alveoli deep within the dorsal lung; these units remain closed and protected from shear injury when $\mathrm{P}_{\text {plat }}$ is limited to $\leq 30 \mathrm{~cm} \mathrm{H}_{2} \mathrm{O}$. Second, in ARDS substantial portions of lung tissue appear to reach full recruitment at $\mathrm{P}_{\text {plat }} \leq 30 \mathrm{~cm} \mathrm{H}_{2} \mathrm{O}$, and its stability appears to be maintained when PEEP is set at $10-15 \mathrm{~cm}$ $\mathrm{H}_{2} \mathrm{O}$. In addition, evidence from several preclinical studies suggests that atelectatic areas are relatively protected from shear injury by intra-alveolar edema, with most damage caused by excessive stress developed in the peripheral airways. ${ }^{178}$ In these studies, tidal overdistention was a more important contributor to pro-inflammatory cytokine expression than shear injury. Third, microimaging of subpleural alveoli in acute lung injury models revealed that, despite stable levels of driving pressure and PEEP, there exist patterns of recruitment and de-recruitment between interdependent alveoli, even at high PEEP levels, that appear to fluctuate minute by minute. ${ }^{138}$ Thus, the notion of eliminating de-recruitment and atelectrauma in ARDS appears illusory.

\section{Implications of Slow Pulmonary Compartments}

Integrating the temporal issues involved in recruitment, with evidence that most recruitment occurs at $\leq 50 \mathrm{~cm}$ $\mathrm{H}_{2} \mathrm{O}$, and the increased mortality risk reported in the ART study, ${ }^{17}$ it behooves us to reflect upon the need for a recruitment maneuver and how it might be approached going forward. Compelling evidence of slow pulmonary compartments in ARDS is at odds with the current recruitment maneuver strategy and raises questions of whether brief recruitment periods reflect the actual effectiveness of a specific $\mathrm{P}_{\text {plat }}$. By extension, this influences the decision to use higher pressures with increasing risk of injury and hemodynamic compromise. Moreover, limited intensity recruitment maneuver studies such as the extended sigh, the prolonged, and the slow moderate recruitment maneuvers cited above all observed substantial recruitment at pressures $\leq 40 \mathrm{~cm} \mathrm{H}_{2} \mathrm{O}$ over a period of several minutes. ${ }^{33-35,37,38}$ To date, no study has investigated whether an extended trial of super-PEEP limited to 25-30 $\mathrm{cm} \mathrm{H}_{2} \mathrm{O}$ and driving pressures of $15 \mathrm{~cm} \mathrm{H}_{2} \mathrm{O}$ might provide sufficiently stable oxygenation over a period of several hours.

Also, the relative importance of using an inspiratory time of 2-3 s during a recruitment maneuver, while supported by preclinical data, has not been evaluated clinically. This strategy substantially limits recruitment maneuvers because it restricts minute ventilation in more severe manifestations of ARDS that are associated with highly elevated physiologic dead space ${ }^{179}$ and places additional strain on rightventricular function. ${ }^{78,170}$ In preclinical studies, an inspiratory time of $1.4 \mathrm{~s}$ is generally sufficient for recruiting the fast pulmonary compartment. ${ }^{180}$ In light of studies describing transient [pulmonary] states, as well as those on prone positioning, it is worth considering whether more clinically appropriate inspiratory times used during LPV, if not optimal, might be sufficient to effect sufficient recruitment over time to reach oxygenation goals.

\section{Hemodynamic Consequences of OLV}

Although it is not the focus of this review, the unexpectedly higher mortality in the OLV arm of the ART study, and its association with a higher incidence of hemodynamic impairment, requires a brief review of cardiothoracic inter-relationships in ARDS and the potential impact of OLV strategies. The pulmonary vasculature functions as a low-resistance, high-capacitance system reflected in the thin-walled right ventricle, which readily shows signs of dysfunction and eventually fails under sustained work demands imposed by high pulmonary vascular resistance in ARDS. ${ }^{170}$

Acute pulmonary hypertension commonly develops in ARDS due to hypoxemia, hypercapnia, acidosis, and pulmonary vascular obstruction from interstitial edema, and disseminated arterial and microvascular embolization. ${ }^{181-184}$ Under mechanical ventilation, conditions of high endinspiratory volume (eg, high PEEP, driving pressure, or a combination of both) markedly increase pulmonary vascular resistance negatively impacts right-ventricular function. ${ }^{185-187}$ Right-ventricular function is further compromised due to the simultaneous reduction in venous return and ventricular preload. Acute cor pulmonale develops when the right ventricle becomes ischemic from sustained excessive workloads; this occurs in 22$25 \%$ of patients with ARDS, with the incidence increasing to 50\% in patients with severe ARDS. ${ }^{188}$ Thus higher PEEP strategies and the potential for recruitment maneuver overuse in response to incidents of desaturation risks the development of either short-term transient hemodynamic instability, which is a common finding in recruitment maneuver studies, ${ }^{189}$ or, more importantly, the potential for longerterm problems of right-ventricular dysfunction and the development of cor pulmonale, which increases mortality risk in patients with ARDS. ${ }^{190}$

\section{Potential Risk of Ventilator-Induced Lung Injury}

A brief comment also seems appropriate regarding the potential risk of pressure control ventilation recruitment maneuver strategies for ventilator-induced lung injury. Although driving pressure is controlled at a seemingly safe level during stepwise increases of super-PEEP (ie, $15 \mathrm{~cm} \mathrm{H}_{2} \mathrm{O}$ ), the overall magnitude of step-changes in airway pressure increase abruptly from 5 or $10 \mathrm{~cm} \mathrm{H}_{2} \mathrm{O}$ to $20 \mathrm{~cm} \mathrm{H}_{2} \mathrm{O}$ as PEEP increases from 25 to $45 \mathrm{~cm}$ 


\section{ReCruitment AND De-Recruitment in ARDS Management}

$\mathrm{H}_{2} \mathrm{O}^{40,72}$ or by continuous incremental changes of $10 \mathrm{~cm}$ $\mathrm{H}_{2} \mathrm{O} .{ }^{17}$ Regardless, these manipulations culminate in extraordinarily high end-inspiratory pressures of $60 \mathrm{~cm}$ $\mathrm{H}_{2} \mathrm{O}$. More concerning is that, during the subsequent PEEP decrement trials in some studies, once the optimal PEEP level is determined, "patients underwent another recruitment maneuver using the same recruiting pressures used in the last step of the maximum recruitment maneuver." 40 This procedure was incorporated into the ART trial. ${ }^{17}$ As others have noted, regardless of the perceived safety of limiting driving pressure to $15 \mathrm{~cm} \mathrm{H}_{2} \mathrm{O}$, there is an upper limit of lung stress that can be tolerated without resulting in severe lung injury. ${ }^{140}$ As described in this review, there appears to exist highly circumspect situations in which this might be appropriate (eg, morbid obesity, abdominal compartment syndrome), although clinicians should always be cognizant of this danger.

\section{Implications of the ART Study}

Finally, the discouraging results of the ART trial underscore the primary clinical problem with recruitment maneuver therapy in ARDS, namely the necessary reliance upon chest radiographs and inferences drawn from mechanistic studies that limits clinicians to mere speculation about the likelihood of therapeutic success. As a result, the vexing problem for clinicians is discerning whether an apparent nonresponder reflects inadequate TOP, insufficient time allotted for recruitment, or simply poor recruitment potential. From what little we are able to discern from the ART trial, this appears to be what occurred: the majority of ARDS cases were from direct injury exhibiting only mild responses to recruitment maneuver, with a correspondingly higher incidence of lung overdistention (surmised from the incidence of barotrauma and need for vasopressor therapy) that was significantly associated with mortality risk in the OLV study arm. ${ }^{17}$

As mentioned above, the accepted standard for assessing lung recruitment is $\mathrm{CT}$ imaging, which provides superior information to identify both the patients who are most likely to benefit from a recruitment maneuver (eg, diffuse injury pattern) and the limits of $\mathrm{P}_{\text {plat }}$ and PEEP based on real-time imaging. Unfortunately, this is clinically impractical, and we therefore remain in the same predicament as the ART study investigators. However, the utilization of bedside ultrasonography in the assessment of lung recruitment is a promising tool and should be incorporated into clinical management when assessing the effectiveness of a recruitment maneuver.

\section{Summary}

In the context of severe ARDS, consideration of a recruitment maneuver should be reserved for a minority of cases with persistent or recurring bouts of hypoxemia that occur despite PEEP levels of $15-20 \mathrm{~cm} \mathrm{H}_{2} \mathrm{O}$ and require prolonged exposure (ie, days) to $\mathrm{F}_{\mathrm{IO}_{2}} \geq 0.70$ to stabilize oxygenation, particularly patients with either intra-abdominal hypertension or severe obesity. Under these circumstances, the risk of exacerbating lung injury from oxidative stress from prolonged exposure to toxic levels of $\mathrm{F}_{\mathrm{IO}_{2}}$ enters prominently into the calculus. ${ }^{169}$ When elevated IAP is not a prominent factor, a prolonged trial of super-PEEP and low driving pressures that generate a $\mathrm{P}_{\text {plat }}$ of $40-45 \mathrm{~cm} \mathrm{H}_{2} \mathrm{O}$ (perhaps in concert with prone position) may be a more prudent approach to stabilize oxygenation. Finally, a recruitment maneuver in those with direct injury and a higher likelihood of pronounced tissue consolidation is probably of limited benefit and has been associated with greater mortality risk.

\section{REFERENCES}

1. Ware LB, Matthay MA. The acute respiratory distress syndrome. N Eng1 J Med 2000;342(18):1334-1349.

2. Kallet RH, Katz JA. Respiratory system mechanics in acute respiratory distress syndrome. Respir Care Clin N Am 2003;9(3):297-319.

3. Suter PM, Fairley B, Isenberg MD. Optimum end-expiratory airway pressure in patients with acute pulmonary failure. N Engl J Med 1975;292(6):284-289.

4. Katz JA, Ozanne GM, Zinn SE, Fairley HB. Time course and mechanisms of lung-volume increase with PEEP in acute pulmonary failure. Anesthesiology 1981;54(1):9-16.

5. Richard JC, Maggiore SM, Jonson B, Mancebo J, Lemaire F, Brochard L. Influence of tidal volume on alveolar recruitment. Respective role of PEEP and a recruitment maneuver. Am J Respir Crit Care Med 2001;163(7):1609-1613.

6. Suzumura EA, Amato MBP, Cavalcanti AB. Understanding recruitment maneuvers. Intensive Care Med 2016;42(5):908-911.

7. Constantin JM, Cayot-Constantin S, Roszyk L, Futier E, Sapin V, Dastugue B, et al. Response to recruitment maneuver influences net alveolar fluid clearance in acute respiratory distress syndrome. Anesthesiology 2007;106(5):944-951.

8. Frank JA, McAuley DF, Gutierrez JA, Daniel BM, Dobbs L, Matthay MA. Differential effects of sustained inflation recruitment maneuvers on alveolar epithelial and lung endothelial injury. Crit Care Med 2005;33(1):181-188.

9. Zhang JG, Chen XJ, Liu F, Zeng ZG, Qian KJ. Lung recruitment maneuver effects on respiratory mechanics and extravascular lung water index in patients with acute respiratory distress syndrome. World $\mathrm{J}$ Emerg Med 2011;2(3):201-205.

10. Chung FT, Lee CS, Lin SM, Kuo CH, Wang TY, Fang YF, et al. Alveolar recruitment maneuver attenuates extravascular lung water in acute respiratory distress syndrome. Medicine (Baltimore) 2017; 96(30):e7627.

11. Bendixen HH, Hedley-Whyte J, Laver MB. Impaired oxygenation in surgical patients during general anesthesia with controlled ventilation. a concept of atelectasis. N Engl J Med 1963;269:991-996.

12. Rothen HU, Neumann P, Berglund JE, Valtysson J, Magnusson A, Hedenstierna G. Dynamics of re-expansion of atelectasis during general anaesthesia. Br J Anaesth 1999;82(4):551-556.

13. Kolton M, Cattran CB, Kent G, Volgyesi G, Froese AB, Bryan AC. Oxygenation during high-frequency ventilation compared with conventional mechanical ventilation in two models of lung injury. Anesth Analg 1982;61(4):323-332. 


\section{ReCruitment AND De-Recruitment in ARDS Management}

14. Lachmann B. Open up the lung and keep the lung open. Intensive Care Med 1992;18(6):319-321.

15. Amato MB, Barbas CS, Medeiros DM, Magaldi RB, Schettino GP, Lorenzi-Filho G, et al. Effect of a protective-ventilation strategy on mortality in the acute respiratory distress syndrome. N Engl J Med 1998;338(6):347-354.

16. Hickling KG. The pressure-volume curve is greatly modified by recruitment. A mathematical model of ARDS lungs. Am J Respir Crit Care Med 1998;158(1):194-202.

17. Writing Group for the Alveolar Recruitment for Acute Respiratory Distress Syndrome Trial Investigators, Cavalcanti AB, Suzumura EA, Laranjeira LN, Paisani DM, Damiani LP, et al. Effect of lung recruitment and titrated positive end-expiratory pressure (PEEP) vs low peep on mortality in patients with acute respiratory distress syndrome: a randomized clinical trial. JAMA 2017;318(14):1335-1345.

18. Acute Respiratory Distress Syndrome Network, Brower RG, Matthay MA, Morris A, Schoenfeld D, Thompson BT, et al. Ventilation with lower tidal volumes as compared with traditional tidal volumes for acute lung injury and the acute respiratory distress syndrome. N Engl J Med 2000;342(18):1301-1308.

19. Sahetya SK, Brower RG. Lung recruitment and titrated PEEP in moderate to severe ARDS. Is the door closing on the open lung? JAMA 2017;318(14):1327-1329.

20. Kallet RH, Lipnick MS. Is there still a role for alveolar recruitment maneuvers in acute respiratory distress syndrome? J Thorac Dis 2018;10(1):85-90.

21. Tugrul S, Akinci O, Ozcan PE, Ince S, Esen F, Telci L. Effects of sustained inflation and postinflation positive end-expiratory pressure in acute respiratory distress syndrome: focusing on pulmonary and extrapulmonary forms. Crit Care Med 2003;31(3):738-744.

22. Brower RG, Morris A, MacIntyre N, Matthay MA, Hayden D, Thompson T, et al. Effects of recruitment maneuvers in patients with acute lung injury and acute respiratory distress syndrome ventilated with high positive end-expiratory pressure. Crit Care Med 2003;31 (11):2592-2597.

23. Oczenski W, Hormann C, Keller C, Lorenzl N, Kepka A, Schwarz S, et al. Recruitment maneuvers after a positive end-expiratory pressure trial do not induce sustained effects in early adult respiratory distress syndrome. Anesthesiology 2004;101(3):620-625.

24. Grasso S, Mascia L, Del Turco M, Malacarne P, Giunta F, Brochard $\mathrm{L}$, et al. Effects of recruiting maneuvers in patients with acute respiratory distress syndrome ventilated with protective ventilatory strategy. Anesthesiology 2002;96(4):795-802.

25. Ingenito EP, Kennedy M. Amplitude-modulated ventilation. Effects in acute lung injury and characterization of mechanisms of action. Chest 1994;105(3 Suppl):63S-66S.

26. Lichtwarck-Aschoff M, Guttmann J, Eberhard L, Fabry B, Birle J, Adolph M. Delayed derecruitment after removal of PEEP in patients with acute lung injury. Acta Anaesthesiol Scand 1997;41(6):675-684.

27. Pelosi P, Cadringher P, Bottino N, Panigada M, Carrieri F, Riva E, et al. Sigh in acute respiratory distress syndrome. Am J Respir Crit Care Med 1999;159(3):872-880.

28. Patroniti N, Foti G, Cortinovis B, Maggioni E, Bigatello LM, Cereda $\mathrm{M}$, et al. Sigh improves gas exchange and lung volume in patients with acute respiratory distress syndrome undergoing pressure support ventilation. Anesthesiology 2002;96(4):788-794.

29. Kallet RH, Siobal MS, Alonso JA, Warnecke EL, Katz JA, Marks JD. Lung collapse during low tidal volume ventilation in acute respiratory distress syndrome. Respir Care 2001;46(1):49-52.

30. Uchida H, Inaba H, Sato J, Sakurada M, Mizuguchi T. Fluctuating PEEP versus conventional PEEP in diffuse and unilateral lung injury induced by oleic acid. Acta Anaesthesiol Scand 1988;32(5):420-425.

31. Lanza FC, Damasceno MC, Leme F, Yagui AC, Paiva KC, Luque A, et al. Variable positive end-expiratory pressure can maintain oxygenation in experimental acute respiratory distress syndrome induced by oleic acid in dogs. Braz J Med Biol Res 2009;42(8):731737.

32. Chiumello D, Marino A, Brioni M, Cigada I, Menga F, Colombo A, et al. Lung recruitment assessed by respiratory mechanics and computed tomography in patients with acute respiratory distress syndrome. What is the relationship? Am J Respir Crit Care Med 2016; 193(11):1254-1263.

33. Rzezinski AF, Oliveira GP, Santiago VR, Santos RS, Ornellas DS, Morales MM, et al. Prolonged recruitment manoeuvre improves lung function with less ultrastructural damage in experimental mild acute lung injury. Respir Physiol Neurobiol 2009;169(3):271-281.

34. Odenstedt H, Lindgren S, Olegard C, Erlandsson K, Lethvall S, Aneman A, et al. Slow moderate pressure recruitment maneuver minimizes negative circulatory and lung mechanic side effects: evaluation of recruitment maneuvers using electric impedance tomography. Intensive Care Med 2005;31(12):1706-1714.

35. Lim CM, Koh Y, Park W, Chin JY, Shim TS, Lee SD, et al. Mechanistic scheme and effect of "extended sigh" as a recruitment maneuver in patients with acute respiratory distress syndrome: a preliminary study. Crit Care Med 2001;29(6):1255-1260.

36. Mahmoud KM, Ammar AS. A comparison between two different alveolar recruitment maneuvers in patients with acute respiratory distress syndrome. Int J Crit Illn Inj Sci 2011;1(2):114-120.

37. Constantin JM, Jaber S, Futier E, Cayot-Constantin S, Verny-Pic M, Jung B, et al. Respiratory effects of different recruitment maneuvers in acute respiratory distress syndrome. Crit Care 2008;12(2):R50.

38. Riva DR, Contador RS, Baez-Garcia CS, Xisto DG, Cagido VR, Martini SV, et al. Recruitment maneuver: RAMP versus CPAP pressure profile in a model of acute lung injury. Respir Physiol Neurobiol 2009;169(1):62-68.

39. Mariani GL, Jonusas SF, Maure C, Esteban M, Pardo A, Rapetti B, et al. Open lung strategy in a lamb model of respiratory distress syndrome. Am J Perinatol 2011;28(8):585-592.

40. Borges JB, Okamoto VN, Matos GF, Caramez MP, Arantes PR, Barros F, et al. Reversibility of lung collapse and hypoxemia in early acute respiratory distress syndrome. Am J Respir Crit Care Med 2006;174(3):268-278.

41. Chiumello D, Mongodi S, Algieri I, Vergani GL, Orlando A, Via G, et al. Assessment of lung aeration and recruitment by CT scan and ultrasound in acute respiratory distress syndrome patients. Crit Care Med 2018;46(11):1761-1768.

42. Riva DR, Oliveira MB, Rzezinski AF, Rangel G, Capelozzi VL, Zin WA, et al. Recruitment maneuver in pulmonary and extrapulmonary experimental acute lung injury. Crit Care Med 2008;36(6):19001908.

43. Gattinoni L, Pelosi P, Suter PM, Pedoto A, Vercesi P, Lissoni A. Acute respiratory distress syndrome caused by pulmonary and extrapulmonary disease. Different syndromes? Am J Respir Crit Care Med 1998;158(1):3-11.

44. Pelosi P, Caironi P, Gattinoni L. Pulmonary and extrapulmonary forms of acute respiratory distress syndrome. Semin Respir Crit Care Med 2001;22(3):259-268.

45. Pires-Neto RC, Morales MM, Lancas T, Inforsato N, Duarte MI, Amato MB, et al. Expression of acute-phase cytokines, surfactant proteins, and epithelial apoptosis in small airways of human acute respiratory distress syndrome. J Crit Care 2013;28(1)111 e119-111 e115.

46. Jain M, Sznajder J. Bench-to-bedside review: distal airways in acute respiratory distress syndrome. Crit Care 2007;11(1):206.

47. Kondili E, Prinianakis G, Athanasakis H, Georgopoulos D. Lung emptying in patients with acute respiratory distress syndrome: effects of positive end-expiratory pressure. Eur Respir J 2002;19(5):811819 . 


\section{ReCruitment AND De-Recruitment in ARDS Management}

48. Gaver DP 3rd, Samsel RW, Solway J. Effects of surface tension and viscosity on airway reopening. J Appl Physiol (1985) 1990;69(1): 74-85.

49. Yap DY, Liebkemann WD, Solway J, Gaver DP 3rd. Influences of parenchymal tethering on the reopening of closed pulmonary airways. J Appl Physiol (1985) 1994;76(5):2095-2105.

50. Low HT, Chew YT, Zhou CW. Pulmonary airway reopening: effects of non-Newtonian fluid viscosity. J Biomech Eng 1997;119(3): 298-308.

51. Naureckas ET, Dawson CA, Gerber BS, Gaver DP 3rd, Gerber HL, Linehan JH, et al. Airway reopening pressure in isolated rat lungs. J Appl Physiol (1985) 1994;76(3):1372-1377.

52. Namati E, Thiesse J, de Ryk J, McLennan G. Alveolar dynamics during respiration: are the pores of Kohn a pathway to recruitment? Am J Respir Cell Mol Biol 2008;38(5):572-578.

53. Matthay MA, Zimmerman GA. Acute lung injury and the acute respiratory distress syndrome: four decades of inquiry into pathogenesis and rational management. Am J Respir Cell Mol Biol 2005;33 (4):319-327.

54. Bachofen M, Weibel ER. Structural alterations of lung parenchyma in the adult respiratory distress syndrome. Clin Chest Med 1982;3 (1):35-56.

55. Lewis JF, Jobe AH. Surfactant and the adult respiratory distress syndrome. Am Rev Respir Dis 1993;147(1):218-233.

56. Martynowicz MA, Walters BJ, Hubmayr RD. Mechanisms of recruitment in oleic acid-injured lungs. J Appl Physiol (1985) 2001;90 (5):1744-1753.

57. Morales MM, Pires-Neto RC, Inforsato N, Lancas T, da Silva LF, Saldiva PH, et al. Small airway remodeling in acute respiratory distress syndrome: a study in autopsy lung tissue. Crit Care 2011; 15(1):R4

58. Gonçalves AD, Alexander C, Roberts CJ, Spain SG, Uddin S, Allen $\mathrm{S}$. The effect of protein concentration on the viscosity of a recombinant albumin solution formulation. RSC Adv 2016;6(18):1514315154.

59. Bates JH, Irvin CG. Time dependence of recruitment and derecruitment in the lung: a theoretical model. J Appl Physiol (1985) 2002;93 (2):705-713.

60. Van de Woestijne KP. Influence of forced inflations on the creep of lungs and thorax in the dog. Respir Physiol 1967;3(1):78-89.

61. Sharp JT, Johnson FN, Goldberg NB, Van Lith P. Hysteresis and stress adaptation in the human respiratory system. J Appl Physiol 1967;23(4):487-497.

62. Bachofen H, Hildebrandt J, Bachofen M. Pressure-volume curves of air- and liquid-filled excised lungs-surface tension in situ. J Appl Physiol 1970;29(4):422-431.

63. Fretschner R, Laubscher TP, Brunner JX. New aspects of pulmonary mechanics: "slowly" distensible compartments of the respiratory system, identified by a PEEP step maneuver. Intensive Care Med 1996;22(12):1328-1334.

64. Nunn J. Applied respiratory physiology. London: Butterworths; 1977:143-150

65. Tugrul S, Cakar N, Akinci O, Ozcan PE, Disci R, Esen F, et al. Time required for equilibration of arterial oxygen pressure after setting optimal positive end-expiratory pressure in acute respiratory distress syndrome. Crit Care Med 2005;33(5):995-1000.

66. Chiumello D, Coppola S, Froio S, Mietto C, Brazzi L, Carlesso E, et al. Time to reach a new steady state after changes of positive end expiratory pressure. Intensive Care Med 2013;39(8):1377-1385.

67. Wolff GE, Guttmann J, Bertschmann W, Zeravik J, Adolph M. Polymorphous ventilation: a new ventilation concept for distributed time constants. In: Rugheimer E, editor. New aspects of respiratory failure. Berlin: Springer; 1992:235-252.
68. Gattinoni L, Pesenti A. The concept of "baby lung". Intensive Care Med 2005;31(6):776-784.

69. Kallet RH. A comprehensive review of prone position in ARDS. Respir Care 2015;60(11):1660-1687.

70. Suwanvanichkij V, Curtis JR. The use of high positive end-expiratory pressure for respiratory failure in abdominal compartment syndrome. Respir Care 2004;49(3):286-290.

71. de Matos GF, Stanzani F, Passos RH, Fontana MF, Albaladejo R, Caserta RE, et al. How large is the lung recruitability in early acute respiratory distress syndrome: a prospective case series of patients monitored by computed tomography. Crit Care 2012;16(1):R4.

72. Povoa P, Almeida E, Fernandes A, Mealha R, Moreira P, Sabino H. Evaluation of a recruitment maneuver with positive inspiratory pressure and high PEEP in patients with severe ARDS. Acta Anaesthesiol Scand 2004;48(3):287-293.

73. Rodriguez PO, Bonelli I, Setten M, Attie S, Madorno M, Maskin LP, et al. Transpulmonary pressure and gas exchange during decremental PEEP titration in pulmonary ARDS patients. Respir Care 2013;58 (5):754-763.

74. Suki B, Alencar AM, Tolnai J, Asztalos T, Petak F, Sujeer MK, et al. Size distribution of recruited alveolar volumes in airway reopening. J Appl Physiol (1985) 2000;89(5):2030-2040.

75. Iannuzzi M, De Sio A, De Robertis E, Piazza O, Servillo G, Tufano R. Different patterns of lung recruitment maneuvers in primary acute respiratory distress syndrome: effects on oxygenation and central hemodynamics. Minerva Anestesiol 2010;76(9):692-698.

76. Gernoth C, Wagner G, Pelosi P, Luecke T. Respiratory and haemodynamic changes during decremental open lung positive end-expiratory pressure titration in patients with acute respiratory distress syndrome. Crit Care 2009;13(2):R59.

77. Lim SC, Adams AB, Simonson DA, Dries DJ, Broccard AF, Hotchkiss JR, et al. Transient hemodynamic effects of recruitment maneuvers in three experimental models of acute lung injury. Crit Care Med 2004;32(12):2378-2384.

78. Vieillard-Baron A, Charron C, Jardin F. Lung "recruitment" or lung overinflation maneuvers? Intensive Care Med 2006;32(1):177-178.

79. Guttmann J, Eberhard L, Fabry B, Bertschmann W, Zeravik J, Adolph M, et al. Time constant/volume relationship of passive expiration in mechanically ventilated ARDS patients. Eur Respir J 1995; 8(1):114-120.

80. Gattinoni L, Caironi P, Cressoni M, Chiumello D, Ranieri VM, Quintel M, et al. Lung recruitment in patients with the acute respiratory distress syndrome. N Engl J Med 2006;354(17):1775-1786.

81. Gattinoni L, Pelosi P, Crotti S, Valenza F. Effects of positive end-expiratory pressure on regional distribution of tidal volume and recruitment in adult respiratory distress syndrome. Am J Respir Crit Care Med 1995;151(6): 1807-1814.

82. Albert SP, DiRocco J, Allen GB, Bates JH, Lafollette R, Kubiak BD, et al. The role of time and pressure on alveolar recruitment. J Appl Physiol (1985) 2009;106(3):757-765.

83. Medoff BD, Harris RS, Kesselman H, Venegas J, Amato MB, Hess D. Use of recruitment maneuvers and high-positive end-expiratory pressure in a patient with acute respiratory distress syndrome. Crit Care Med 2000;28(4):1210-1216.

84. Kacmarek RM, Kallet RH. Respiratory controversies in the critical care setting. Should recruitment maneuvers be used in the management of ALI and ARDS? Respir Care 2007;52(5):622-631.

85. Crotti S, Mascheroni D, Caironi P, Pelosi P, Ronzoni G, Mondino M, et al. Recruitment and derecruitment during acute respiratory failure: a clinical study. Am J Respir Crit Care Med 2001;164(1):131-140.

86. Schreiter D, Reske A, Stichert B, Seiwerts M, Bohm SH, Kloeppel $\mathrm{R}$, et al. Alveolar recruitment in combination with sufficient positive end-expiratory pressure increases oxygenation and lung aeration in 


\section{ReCruitment AND De-Recruitment in ARDS Management}

patients with severe chest trauma. Crit Care Med 2004;32(4):968975.

87. Cherniack R, Cherniak L, Naimark A. Respiration in health and disease. Philadelphia: W.B. Saunders Company; 1972:136-137.

88. Murray JF. The normal lung. The basis for diagnosis and treatment of pulmonary disease. Philadelphia: W.B. Saunders; 1976:14-17.

89. Kallet RH. Should PEEP titration be based on chest mechanics in patients with ARDS? Respir Care 2016;61(6):876-890.

90. Albaiceta GM, Taboada F, Parra D, Luyando LH, Calvo J, Menendez $\mathrm{R}$, et al. Tomographic study of the inflection points of the pressurevolume curve in acute lung injury. Am J Respir Crit Care Med 2004;170(10):1066-1072.

91. Jonson B, Richard JC, Straus C, Mancebo J, Lemaire F, Brochard L. Pressure-volume curves and compliance in acute lung injury: evidence of recruitment above the lower inflection point. Am J Respir Crit Care Med 1999;159(4):1172-1178.

92. Caironi P, Cressoni M, Chiumello D, Ranieri M, Quintel M, Russo $\mathrm{SG}$, et al. Lung opening and closing during ventilation of acute respiratory distress syndrome. Am J Respir Crit Care Med 2010;181 (6):578-586.

93. Coppola S, Froio S, Marino A, Brioni M, Cesana BM, Cressoni M, et al. Respiratory mechanics, lung recruitability, and gas exchange in pulmonary and extrapulmonary acute respiratory distress syndrome. Crit Care Med 2019;47(6):792-799.

94. Cressoni M, Chiumello D, Carlesso E, Chiurazzi C, Amini M, Brioni $\mathrm{M}$, et al. Compressive forces and computed tomography-derived positive end-expiratory pressure in acute respiratory distress syndrome. Anesthesiology 2014;121(3):572-581.

95. Toth I, Leiner T, Mikor A, Szakmany T, Bogar L, Molnar Z. Hemodynamic and respiratory changes during lung recruitment and descending optimal positive end-expiratory pressure titration in patients with acute respiratory distress syndrome. Crit Care Med 2007;35(3):787-793.

96. Santiago VR, Rzezinski AF, Nardelli LM, Silva JD, Garcia CS, Maron-Gutierrez T, et al. Recruitment maneuver in experimental acute lung injury: the role of alveolar collapse and edema. Crit Care Med 2010;38(11):2207-2214.

97. Pelosi P, Gama de Abreu M, Rocco PR. New and conventional strategies for lung recruitment in acute respiratory distress syndrome. Crit Care 2010;14(2):210.

98. Smetkin AA, Kuzkov VV, Suborov EV, Bjertnaes LJ, Kirov MY. Increased extravascular lung water reduces the efficacy of alveolar recruitment maneuver in acute respiratory distress syndrome. Crit Care Res Pract 2012;2012:606528.

99. Gattinoni L, Pesenti A, Carlesso E. Body position changes redistribute lung computed-tomographic density in patients with acute respiratory failure: impact and clinical fallout through the following 20 years. Intensive Care Med 2013;39(11):1909-1915.

100. Ware LB, Matthay MA. Alveolar fluid clearance is impaired in the majority of patients with acute lung injury and the acute respiratory distress syndrome. Am J Respir Crit Care Med 2001;163(6):13761383.

101. Villagra A, Ochagavia A, Vatua S, Murias G, Del Mar Fernandez M, Lopez Aguilar J, et al. Recruitment maneuvers during lung protective ventilation in acute respiratory distress syndrome. Am J Respir Crit Care Med 2002; 165(2):165-170.

102. Johannigman JA, Miller SL, Davis BR, Davis K Jr, Campbell RS, Branson RD. Influence of low tidal volumes on gas exchange in acute respiratory distress syndrome and the role of recruitment maneuvers. J Trauma 2003;54(2):320-325.

103. Gattinoni L, Carlesso E, Cressoni M. Selecting the 'right' positive end-expiratory pressure level. Curr Opin Crit Care 2015;21(1):50-57.
104. Agostoni E, D'Angelo E, Bonanni MV. The effect of the abdomen on the vertical gradient of pleural surface pressure. Respir Physiol 1970;8(3):332-346.

105. Hedenstierna G, Strandberg A, Brismar B, Lundquist H, Svensson L, Tokics L. Functional residual capacity, thoracoabdominal dimensions, and central blood volume during general anesthesia with muscle paralysis and mechanical ventilation. Anesthesiology 1985;62 (3):247-254.

106. Regli A, Pelosi P, Malbrain M. Ventilation in patients with intra-abdominal hypertension: what every critical care physician needs to know. Ann Intensive Care 2019;9(1):52.

107. Mutoh T, Lamm WJ, Embree LJ, Hildebrandt J, Albert RK. Abdominal distension alters regional pleural pressures and chest wall mechanics in pigs in vivo. J Appl Physiol (1985) 1991;70(6):26112618.

108. Ranieri VM, Brienza N, Santostasi S, Puntillo F, Mascia L, Vitale N, et al. Impairment of lung and chest wall mechanics in patients with acute respiratory distress syndrome: role of abdominal distension. Am J Respir Crit Care Med 1997;156(4 Pt 1):1082-1091.

109. Sharp JT, Henry JP, Sweany SK, Meadows WR, Pietras RJ. Total respiratory inertance and its gas and tissue components in normal and obese men. J Clin Invest 1964;43:503-509.

110. Ertel W, Oberholzer A, Platz A, Stocker R, Trentz O. Incidence and clinical pattern of the abdominal compartment syndrome after "damage-control" laparotomy in 311 patients with severe abdominal and/ or pelvic trauma. Crit Care Med 2000;28(6):1747-1753.

111. Zhou JC, Xu QP, Pan KH, Mao C, Jin CW. Effect of increased intraabdominal pressure and decompressive laparotomy on aerated lung volume distribution. J Zhejiang Univ Sci B 2010;11(5):378-385.

112. Kessler V, Ramirez J, Braun G, Mols G, Guttmann J. Respiratory system inertance: investigation in a physical inertance model. The 2000;8(1):1-14.

113. Amato MB, Meade MO, Slutsky AS, Brochard L, Costa EL, Schoenfeld DA, et al. Driving pressure and survival in the acute respiratory distress syndrome. N Engl J Med 2015;372(8):747-755.

114. De Keulenaer BL, De Waele JJ, Powell B, Malbrain ML. What is normal intra-abdominal pressure and how is it affected by positioning, body mass and positive end-expiratory pressure? Intensive Care Med 2009;35(6):969-976.

115. Bellani G, Laffey JG, Pham T, Fan E, Brochard L, Esteban A, et al. Epidemiology, patterns of care, and mortality for patients with acute respiratory distress syndrome in intensive care units in 50 countries. JAMA 2016;315(8):788-800.

116. Krebs J, Pelosi P, Tsagogiorgas C, Alb M, Luecke T. Effects of positive end-expiratory pressure on respiratory function and hemodynamics in patients with acute respiratory failure with and without intraabdominal hypertension: a pilot study. Crit Care 2009;13(5):R160.

117. Regli A, Mahendran R, Fysh ET, Roberts B, Noffsinger B, De Keulenaer BL, et al. Matching positive end-expiratory pressure to intra-abdominal pressure improves oxygenation in a porcine sick lung model of intra-abdominal hypertension. Crit Care 2012;16(5): R208.

118. Quintel M, Pelosi P, Caironi P, Meinhardt JP, Luecke T, Herrmann $\mathrm{P}$, et al. An increase of abdominal pressure increases pulmonary edema in oleic acid-induced lung injury. Am J Respir Crit Care Med 2004; 169(4):534-541.

119. Yang Y, Li Y, Liu SQ, Liu L, Huang YZ, Guo FM, et al. Positive end expiratory pressure titrated by transpulmonary pressure improved oxygenation and respiratory mechanics in acute respiratory distress syndrome patients with intra-abdominal hypertension. Chin Med J (Engl) 2013;126(17):3234-3239.

120. Kallet R, Katz JA, Pittet JF, Ghermey J, Siobal M, Alonso JA, Marks JD. Measuring intraesophageal pressure to assess transmural pulmonary arterial occlusion pressure in patients with clinical acute lung 


\section{ReCruitment AND De-Recruitment in ARDS Management}

injury: a case series report and review. Respir Care 2000;45(9):10721084.

121. Regli A, Hockings LE, Musk GC, Roberts B, Noffsinger B, Singh B, et al. Commonly applied positive end-expiratory pressures do not prevent functional residual capacity decline in the setting of intra-abdominal hypertension: a pig model. Crit Care 2010;14(4):R128.

122. Cullen DJ, Coyle JP, Teplick R, Long MC. Cardiovascular, pulmonary, and renal effects of massively increased intra-abdominal pressure in critically ill patients. Crit Care Med 1989;17(2):118-121.

123. Pelosi $\mathrm{P}$, Vargas $\mathrm{M}$. Mechanical ventilation and intra-abdominal hypertension: 'beyond good and evil'. Crit Care 2012;16(6):187.

124. Cinnella G, Grasso S, Raimondo P, D'Antini D, Mirabella L, Rauseo $\mathrm{M}$, et al. Physiological effects of the open lung approach in patients with early, mild, diffuse acute respiratory distress syndrome: an electrical impedance tomography study. Anesthesiology 2015;123(5): 1113-1121.

125. Ball L, Vercesi V, Costantino F, Chandrapatham K, Pelosi P. Lung imaging: how to get better look inside the lung. Ann Transl Med 2017;5(14):294.

126. Pelosi P, Gattinoni L. Acute respiratory distress syndrome of pulmonary and extra-pulmonary origin: fancy or reality? Intensive Care Med 2001;27(3):457-460.

127. Gattinoni L, Pelosi P, Vitale G, Pesenti A, D'Andrea L, Mascheroni D. Body position changes redistribute lung computed-tomographic density in patients with acute respiratory failure. Anesthesiology 1991;74(1):15-23.

128. Vieira SR, Puybasset L, Richecoeur J, Lu Q, Cluzel P, Gusman PB, et al. A lung computed tomographic assessment of positive end-expiratory pressure-induced lung overdistension. Am J Respir Crit Care Med 1998;158(5 Pt 1):1571-1577.

129. Lu Q, Malbouisson LM, Mourgeon E, Goldstein I, Coriat P, Rouby JJ. Assessment of PEEP-induced reopening of collapsed lung regions in acute lung injury: are one or three CT sections representative of the entire lung? Intensive Care Med 2001;27(9):1504-1510.

130. Malbouisson LM, Muller JC, Constantin JM, Lu Q, Puybasset L, Rouby JJ, CT Scan ARDS Study Group. Computed tomography assessment of positive end-expiratory pressure-induced alveolar recruitment in patients with acute respiratory distress syndrome. Am J Respir Crit Care Med 2001;163(6):1444-1450.

131. Ralph DD, Robertson HT, Weaver LJ, Hlastala MP, Carrico CJ, Hudson LD. Distribution of ventilation and perfusion during positive end-expiratory pressure in the adult respiratory distress syndrome. Am Rev Respir Dis 1985;131(1):54-60.

132. Dantzker DR, Lynch JP, Weg JG. Depression of cardiac output is a mechanism of shunt reduction in the therapy of acute respiratory failure. Chest 1980;77(5):636-642

133. Hasinoff I, Ducas J, Prewitt RM. Increased cardiac output increases lung water in canine permeability pulmonary edema. J Crit Care 1988;3(4):225-231.

134. Malo J, Ali J, Wood LD. How does positive end-expiratory pressure reduce intrapulmonary shunt in canine pulmonary edema? J Appl Physiol Respir Environ Exerc Physiol 1984;57(4):1002-1010.

135. Hubmayr RD. Perspective on lung injury and recruitment: a skeptical look at the opening and collapse story. Am J Respir Crit Care Med 2002; 165(12):1647-1653.

136. Kitaoka H, Tamura S, Takaki R. A three-dimensional model of the human pulmonary acinus. J Appl Physiol (1985) 2000;88(6):22602268.

137. Tabuchi A, Nickles HT, Kim M, Semple JW, Koch E, Brochard L, et al. Acute lung injury causes asynchronous alveolar ventilation that can be corrected by individual sighs. Am J Respir Crit Care Med 2016;193(4):396-406.

138. Broche L, Perchiazzi G, Porra L, Tannoia A, Pellegrini M, Derosa S, et al. Dynamic mechanical interactions between neighboring airspaces determine cyclic opening and closure in injured lung. Crit Care Med 2017;45(4):687-694.

139. Bates JHT, Smith BJ. Ventilator-induced lung injury and lung mechanics. Ann Transl Med 2018;6(19):378.

140. Hubmayr RD, Kallet RH. Understanding pulmonary stress-strain relationships in severe ARDS and its implications for designing a safer approach to setting the ventilator. Respir Care 2018;63(2):219226.

141. Heil M, Hazel AL, Smith JA. The mechanics of airway closure. Respir Physiol Neurobiol 2008;163(1-3):214-221.

142. Katzenstein AL, Bloor CM, Leibow AA. Diffuse alveolar damagethe role of oxygen, shock, and related factors. A review. Am J Pathol 1976;85(1):209-228.

143. Nash G, Blennerhassett JB, Pontoppidan H. Pulmonary lesions associated with oxygen therapy and artifical ventilation. N Engl J Med 1967;276(7):368-374.

144. Gomez AC. Pulmonary insufficiency in nonthoracic trauma. J Trauma 1968;8(5):656-686.

145. Simeone FA. Pulmonary complications of nonthoracic wounds: a historical perspective. J Trauma 1968;8(5):625-648.

146. Lamy ML, Fallat RJ, Koeniger EL, Dietrich HP, Kamm B, Hill JD. Pathophysiology of adult respiratory distress syndrome. Acta Anaesthesiol Belg 1975;23 Suppl:64-77.

147. Berry REL, Sanislow CA. Clinical manifestations and treatment of congestive atelectasis. Arch Surg 1963;87(1):153-167.

148. Blaisdell FW, Schlobohm RM. The respiratory distress syndrome: a review. Surgery 1973;74(2):251-262.

149. Soloway HB, Castillo Y, Martin AM, Jr. Adult hyaline membrane disease: relationship to oxygen therapy. Ann Surg 1968;168(6):937945.

150. Nash G. Pathology of ARDS. West J Med 1979;130(3):220-222.

151. Petty TL, Silvers GW, Paul GW, Stanford RE. Abnormalities in lung elastic properties and surfactant function in adult respiratory distress syndrome. Chest 1979;75(5):571-574.

152. Simmons RL, Heisterkamp CA 3rd, Collins JA, Bredenburg CE, Martin AM. Acute pulmonary edema in battle casualties. J Trauma 1969;9(9):760-775.

153. Ashbaugh DG, Bigelow DB, Petty TL, Levine BE. Acute respiratory distress in adults. Lancet 1967;290(7511):319-323.

154. Puybasset L, Cluzel P, Gusman P, Grenier P, Preteux F, Rouby JJ. Regional distribution of gas and tissue in acute respiratory distress syndrome. I. Consequences for lung morphology. CT Scan ARDS Study Group. Intensive Care Med 2000;26(7):857-869.

155. Thille AW, Esteban A, Fernandez-Segoviano P, Rodriguez JM, Aramburu JA, Vargas-Errazuriz P, et al. Chronology of histological lesions in acute respiratory distress syndrome with diffuse alveolar damage: a prospective cohort study of clinical autopsies. Lancet Respir Med 2013;1(5):395-401.

156. Cardinal-Fernandez P, Lorente JA, Ballen-Barragan A, Matute-Bello G. Acute respiratory distress syndrome and diffuse alveolar damage: new insights on a complex relationship. Ann Am Thorac Soc 2017;14(6):844-850.

157. Matthay MA, Zemans RL, Zimmerman GA, Arabi YM, Beitler JR, Mercat A, et al. Acute respiratory distress syndrome. Nat Rev Dis Primers 2019;5(1): 18 .

158. Kao KC, Hu HC, Chang CH, Hung CY, Chiu LC, Li SH, et al. Diffuse alveolar damage associated mortality in selected acute respiratory distress syndrome patients with open lung biopsy. Crit Care 2015; 19(1):228.

159. Lamy M, Fallat RJ, Koeniger E, Dietrich HP, Ratliff JL, Eberhart $\mathrm{RC}$, et al. Pathologic features and mechanisms of hypoxemia in adult respiratory distress syndrome. Am Rev Respir Dis 1976;114(2):267284. 


\section{ReCruitment AND De-Recruitment in ARDS Management}

160. Pelosi P, D’Onofrio D, Chiumello D, Paolo S, Chiara G, Capelozzi VL, et al. Pulmonary and extrapulmonary acute respiratory distress syndrome are different. Eur Respir J Suppl 2003;42:48s-56s.

161. Morisawa K, Fujitani S, Taira Y, Kushimoto S, Kitazawa Y, Okuchi $\mathrm{K}$, et al. Difference in pulmonary permeability between indirect and direct acute respiratory distress syndrome assessed by the transpulmonary thermodilution technique: a prospective, observational, multi-institutional study. J Intensive Care 2014;2(1):24.

162. Terashima T, Matsubara H, Nakamura M, Sakamaki F, Waki Y, Soejima K, et al. Local Pseudomonas instillation induces contralateral lung injury and plasma cytokines. Am J Respir Crit Care Med 1996;153(5):1600-1605.

163. Kallet RH, Lipnick MS, Zhuo H, Pangilinan LP, Gomez A. Characteristics of nonpulmonary organ dysfunction at onset of ARDS based on the Berlin definition. Respir Care 2019;64(5):493501.

164. Kushimoto S, Endo T, Yamanouchi S, Sakamoto T, Ishikura H, Kitazawa Y, et al. Relationship between extravascular lung water and severity categories of acute respiratory distress syndrome by the Berlin definition. Crit Care 2013;17(4):R132.

165. Vieira SR, Puybasset L, Lu Q, Richecoeur J, Cluzel P, Coriat P, et al. A scanographic assessment of pulmonary morphology in acute lung injury. Significance of the lower inflection point detected on the lung pressure-volume curve. Am J Respir Crit Care Med 1999;159 (5):1612-1623.

166. Puybasset L, Cluzel P, Chao N, Slutsky AS, Coriat P, Rouby JJ. A computed tomography scan assessment of regional lung volume in acute lung injury. The CT Scan ARDS Study Group. Am J Respir Crit Care Med 1998;158(5 Pt 1):1644-1655.

167. Puybasset L, Gusman P, Muller JC, Cluzel P, Coriat P, Rouby JJ. Regional distribution of gas and tissue in acute respiratory distress syndrome. III. Consequences for the effects of positive end-expiratory pressure. CT Scan ARDS Study Group. Adult Respiratory Distress Syndrome. Intensive Care Med 2000;26(9):1215-1227.

168. Albert RK. Least PEEP: primum non nocere. Chest 1985;87(1):2-4.

169. Kallet RH, Matthay MA. Hyperoxic acute lung injury. Respir Care 2013;58(1):123-141

170. Paternot A, Repesse X, Vieillard-Baron A. Rationale and description of right ventricle-protective ventilation in ARDS. Respir Care 2016;61(10):1391-1396.

171. Jardin F, Vieillard-Baron A. Is there a safe plateau pressure in ARDS? The right heart only knows. Intensive Care Med 2007;33 (3):444-447.

172. Rouby JJ, Brochard L. Tidal recruitment and overinflation in acute respiratory distress syndrome: yin and yang. Am J Respir Crit Care Med 2007;175(2):104-106.

173. Brower RG, Lanken PN, MacIntyre N, Matthay MA, Morris A, Ancukiewicz M, et al. Higher versus lower positive end-expiratory pressures in patients with the acute respiratory distress syndrome. $\mathrm{N}$ Engl J Med 2004;351(4):327-336.

174. Mercat A, Richard JC, Vielle B, Jaber S, Osman D, Diehl JL, et al. Positive end-expiratory pressure setting in adults with acute lung injury and acute respiratory distress syndrome: a randomized controlled trial. JAMA 2008;299(6):646-655.
175. Meade MO, Cook DJ, Guyatt GH, Slutsky AS, Arabi YM, Cooper DJ, et al. Ventilation strategy using low tidal volumes, recruitment maneuvers, and high positive end-expiratory pressure for acute lung injury and acute respiratory distress syndrome: a randomized controlled trial. JAMA 2008;299(6):637-645.

176. Kallet RH, Alonso JA, Pittet JF, Matthay MA. Prognostic value of the pulmonary dead-space fraction during the first 6 days of acute respiratory distress syndrome. Respir Care 2004;49(9):1008-1014.

177. Murray JF. The normal lung. The basis for diagnosis and treatment of pulmonary disease. Philadelphia: W.B. Saunders; 1976:186-187.

178. Pelosi P, Rocco PRM, Gama de Abreu M. Close down the lungs and keep them resting to minimize ventilator-induced lung injury. Crit Care 2018;22(1):72.

179. Kallet RH, Zhuo H, Ho K, Lipnick MS, Gomez A, Matthay MA. Lung injury etiology and other factors influencing the relationship between dead-space fraction and mortality in ARDS. Respir Care 2017;62(10):1241-1248

180. Neumann P, Berglund JE, Mondejar EF, Magnusson A, Hedenstierna G. Effect of different pressure levels on the dynamics of lung collapse and recruitment in oleic-acid-induced lung injury. Am J Respir Crit Care Med 1998;158(5):1636-1643.

181. Tomashefski JF, Jr., Davies P, Boggis C, Greene R, Zapol WM, Reid LM. The pulmonary vascular lesions of the adult respiratory distress syndrome. Am J Pathol 1983;112(1):112-126.

182. Moloney ED, Evans TW. Pathophysiology and pharmacological treatment of pulmonary hypertension in acute respiratory distress syndrome. Eur Respir J 2003;21(4):720-727.

183. Marhong J, Fan E. Carbon dioxide in the critically ill: too much or too little of a good thing? Respir Care 2014;59(10):1597-1605.

184. Curley GF, Laffey JG. Acidosis in the critically ill - balancing risks and benefits to optimize outcome. Crit Care 2014;18(2):129.

185. Koganov Y, Weiss YG, Oppenheim A, Elami A, Pizov R. Positive end-expiratory pressure increases pulmonary venous vascular resistance in patients after coronary artery surgery. Crit Care Med 1997;25 (5):767-772.

186. Jardin F, Brun-Ney D, Cazaux P, Dubourg O, Hardy A, Bourdarias JP. Relation between transpulmonary pressure and right ventricular isovolumetric pressure change during respiratory support. Cathet Cardiovasc Diagn 1989;16(4):215-220.

187. Vieillard-Baron A, Jardin F. Why protect the right ventricle in patients with acute respiratory distress syndrome? Curr Opin Crit Care 2003;9(1):15-21.

188. Vieillard-Baron A, Price LC, Matthay MA. Acute cor pulmonale in ARDS. Intensive Care Med 2013;39(10):1836-1838.

189. Pensier J, de Jong A, Hajjej Z, Molinari N, Carr J, Belafia F, et al. Effect of lung recruitment maneuver on oxygenation, physiological parameters and mortality in acute respiratory distress syndrome patients: a systematic review and meta-analysis. Intensive Care Med 2019;45(12):1691-1702.

190. Boissier F, Katsahian S, Razazi K, Thille AW, Roche-Campo F, Leon R, et al. Prevalence and prognosis of cor pulmonale during protective ventilation for acute respiratory distress syndrome. Intensive Care Med 2013;39(10):1725-1733. 